\title{
Why do natives and non-natives have different housing outcomes? Evidence from Britain
}

Article

Accepted Version

Oladiran, O., Nanda, A. and Milcheva, S. (2019) Why do natives and non-natives have different housing outcomes? Evidence from Britain. International Journal of Housing Markets and Analysis, 12 (2). pp. 298-329. ISSN 1753-8270 doi: https://doi.org/10.1108/IJHMA-10-2018-0084 Available at https://centaur.reading.ac.uk/80895/

It is advisable to refer to the publisher's version if you intend to cite from the work. See Guidance on citing.

To link to this article DOI: http://dx.doi.org/10.1108/IJHMA-10-2018-0084

Publisher: Emerald

All outputs in CentAUR are protected by Intellectual Property Rights law, including copyright law. Copyright and IPR is retained by the creators or other copyright holders. Terms and conditions for use of this material are defined in the End User Agreement.

www.reading.ac.uk/centaur 
Central Archive at the University of Reading

Reading's research outputs online 


\title{
Why do Natives and non-natives have different Housing Outcomes? Evidence from
}

\section{Britain}

\author{
Abstract: \\ Purpose: \\ In this study, we examine the housing outcomes of natives and multiple generations of non-natives \\ using a longitudinal survey data in Britain. \\ Design/methodology/approach \\ We use longitudinal data from Britain, in which we can observe multiple generations of immigrants \\ and their demographic and economic information. \\ Findings \\ The probability models for housing tenure reveal significant variation in the outcomes which are \\ robust to several econometric specifications. \\ Research limitations/implications \\ Since migration and its impact on local economy is highly debated topic across several major regions \\ of the world, the findings bring out important insights with policy implications. The research is \\ limited by the sample size of the longitudinal survey. \\ Originality/value \\ The empirical evidence on the topic is quite limited with mixed findings. Especially, our ability to \\ look through multiple generations is unique in identifying the variation in housing outcomes for the \\ native and non-native citizens.
}

Keywords: migration, housing, tenure, longitudinal survey data 


\section{Introduction and background}

The recent pace of immigration across Europe has generated a plethora of debates and discussion at all levels of policy-making and public discourse. Migration is a complex and ubiquitous phenomenon, and while international migration has been a long-standing trend, the recent uptick in volume and complexity in the drivers and impacts have resulted in deliberation of old debates, one of them is the impact on the urban environment. In Britain, the recent change in the pace and breath of migration are significantly changing the outlook and urban landscape, notably the housing market. Britain attracted a high number of immigrants from around the world in the last half century which has led to extensive policy formulation and modification, as well as economic and political debates ${ }^{1}$. Recent projections (Cangiano, 2018) however suggest that despite Brexit, approximately $60 \%$ of the projected population growth in Britain by 2040 will still be attributable to migration (from all countries) which will have significant implications for the UK housing market. Britain has traditionally attracted a proportionately high number of migrants from South Asia (Figure 1).

\section{[INSERT Figure 1]}

Housing is a key element of the migrants' journey; hence Britain's housing pattern is constantly evolving with waves of immigration. One of the key housing market dynamics caused by net migration in Britain is the variation in housing tenure trends for natives and non-natives ${ }^{2}$. The variation in housing tenure outcomes for natives, second-generation

\footnotetext{
${ }^{1}$ The Migration Observatory (2016a and 2016b) culminating in the UK referendum on EU membership in June 2016 which saw the majority of the UK population voting to exit the EU (Brexit).

${ }^{2}$ A lot of debates surround the classification of natives and immigrants, particularly relating to the children of immigrants. Migration economists conventionally adopt the implicit use of the term "immigrants" as individuals that reside in a different country from their country of birth, and natives are intuitively classified as individuals residing in the country that they were born. However, these classifications are questionable, particularly if an individual, though residing in the same country that he/she was born, has immigrant parents. The key contention is that the classification of immigrants as individuals residing in a country different from their country of birth excludes their children, and though born in the country of residence, their children do not automatically qualify as "natives". This is exacerbated by the evidence that children born to immigrant parents usually have different life pathways in terms of their educational performance, acculturation adaptation, language, local knowledge, physical, psychological and labour market outcomes from their parents and from other children born to natives (Keeley 2009; Behtoui and Olsson 2014). This has advanced the definition of nativity beyond place of birth to parental place of birth also. Keeley (2009) offers what appears to be a clear and simple definition of immigrants and their children that were born in the country where they settled by classifying migrant "generations". He classifies first generation immigrants as individuals born in a different country from their country of residence and second generation immigrants as those whose parents were born in another country but who themselves were born in the country where their parents settled. This implies that only individuals born in the country of residence to parents who were also born in the same country can be categorised as natives.

Rumbaut (2004) however argues that place of birth and parental nativity alone may be insufficient in determining migration generations. He argues that the life stage or age at the time of immigration may be key in determining their migration generation, suggesting that the "whole number" classification of first generation migrants, second generation migrants and natives (as adopted in Keeley, 2009) may insufficiently account for this complexity. He therefore proposes a further decomposition of first generation migrants based on their age at migration and re-categorises natives and migrants in what can be termed "decimal calibration" (1.0 for those who migrated at over age 18 ; 1.25 for those who migrated from age $13-17 ; 1.50$ for those who migrated from age $6-12 ; 1.75$ for those who migrated from age $0-5 ; 2.0$ for those born in the resident country to immigrant parents; and 3.0 to individuals born in the resident country to native parents) which captures nativity, parental background and life stage when migration occurred. Our research however adopts the traditional whole number classification (similar to Keeley, 2009) to maintain simplicity; the decimal classification test is therefore encouraged in further research.
} 
migrants and first-generation migrants as shown in Figure 2 reveals that first-generation migrants have different homeownership/rental outcomes from the general population and this has implications on housing demand. Specifically, this evidence reveals that the proportion of homeowners ${ }^{3}$ is much higher for natives than for non-natives ${ }^{4}$, suggesting that an increase in immigration may lead to growth in the demand on the rental market at a higher rate than the sales market and mortgage markets. Scholars (Rumbaut, 2004; Keeley 2009; Behtoui and Olsson 2014) further suggest that it may be worthy to analyse second-generation migrants as a separate cohort from first-generation migrants, and natives. However, there is an absence of empirical evidence in this regard in Britain. We therefore aim to fill this gap by taking account of this cohort variability in our empirical analyse of housing tenure variations, and to further analyse the mechanism and factors driving these variations for natives, firstgeneration and second-generation migrants in Britain.

Further evidence (Figure 3) reveals that housing tenure differs significantly across the migrant groups in terms of country of origin.

\section{[INSERT Figures 2, 3]}

At the same time, the housing outcomes and pathways depend on lifecycle phase and associated parameters. More important, we also find that there is a market variation among the first-generation migrants based on their migration lifecycle ${ }^{5}$.

\section{[INSERT Figures 4, 5]}

However, the variations shown in Figures 2, 3, 4 and 5 are merely descriptive and thus insufficient basis for projections, forecasting, planning and policy formulation. This therefore creates the need for further empirical analysis of these factors.

The projected increase in the population growth attributable to immigration suggests that immigrants will have a significant impact on housing over the next century. It is therefore important to analyse previous and present migration effects on housing tenure in order to adequately make provision for the expected changes from the imminent immigration. Furthermore, housing tenure models in previous studies are seldom analysed in

\footnotetext{
${ }^{3}$ Relative to renters

${ }^{4}$ First and second-generation migrants

${ }^{5}$ The number of years spent in the country
} 
heterogeneous models (separating native and non-native cohorts in different models), and the results obtained from homogenous models may be less precise, particularly in application to certain migrant cohorts. Analysing natives and non-natives' housing tenure outcomes in separate models may therefore improve precision and by effect, enhance clarity in forecasting, planning and formulation of policies. Furthermore, with an obvious gap in housing literature regarding the presence or absence of a variation in housing outcomes on the basis of the traditional migration generations, we will make an important contribution by testing these migration generational variations.

This paper therefore aims to empirically analyse key factors which may be driving the variation in housing tenure outcomes (particularly homeownership and rental) for natives and non-natives. We test these factors using heterogeneous models. Specifically, we ask: which factors are likely to increase and decrease the likelihood of homeownership and renting for natives and non-natives? We expect to be able to explain the variation in tenure outcomes for natives and non-natives from the process.

\section{Literature Review}

Conceptual and Theoretical Framework

There is a significant body of literature on variation in housing tenure choices and outcomes, and a vast proportion of these literature focus on ethnic and racial variations. While these studies (such as Skifter Andersen et al. 2016) reveal homeownership variation on ethnic and racial basis, they fail to account for key immigration effects. This has been addressed with studies (such as Coulson 1999; Painter et al. 2001; Borjas 2002) modelling homeownership variations between ethnic groups, while accounting for immigration effects. However, these studies adopt homogenous modelling which may fail to capture the different effects of key factors that may be influencing housing tenure outcomes on the different migrant generational cohorts. While Coulson (1999) adopts heterogeneous modelling, the focus is on the variation in the effects of key variables on different ethnic groups, rather than migrant cohorts. However, analysing ethnic variations in housing outcomes may still be insufficient because there may be more fundamentally different effects within these ethnicities based on their immigration generation. For instance, a native of a particular ethnic group may act differently from a first-generation or second-generation migrant of the same ethnic group. This is a key research gap we aim to fill, particularly by adopting heterogeneous modelling 
and accounting for the second-generation migrants who are often not the subject of housing research. We hypothesis that the key factors that influence housing tenure outcomes will have varying degrees of impact on members of the different generations, hence delineating the sample into optimal subsets in our analysis may offer better insight and accuracy to predicting housing tenure outcomes.

\section{Determinants of Housing Tenure Outcomes}

Housing tenure outcomes are traditionally linked to socio-economic, locational, individual, household, demographic and sociocultural factors. We summarise the existing scholarly perspectives on these factors, and these serve as the theoretical underpinning for our research. We also identify further gaps in knowledge and highlight how our contribution addresses these gaps.

\section{Socio-economic effects}

Literature reveals that socio-economic factors are key in determining housing outcomes (Kuebler and Rugh, 2013; Gyourko and Linneman 1999; Ihlanfeldt 1986; Rosenthal, Duca and Gabriel 1991). Housing tenure outcomes are theoretically linked to affordability, specifically household income, labour market conditions, house prices, and credit constraint. However, these are hardly analysed in the context of nativity and immigration. Studies such as Zorlu et al. (2014) however investigate homeownership rates variation for natives and nonnatives. They find that human capital endowment of individuals such as education, work experience, income generation capability and positive inclination to invest in housing are key drivers of homeownership. Coulson (1999) further reveal that house values, home purchase cost, educational attainment, and information asymmetry in the housing market also influence housing tenure choices. They however observe that income effects are inconsistent because Hispanics and Asians despite having higher income than blacks have lower homeownership rates.

Hall and Greenman (2013) offer more perspectives on socio-economic effects by showing that legal status of immigrants (being an undocumented/ illegal immigrant) may further exacerbate their socio-economic status. They suggest that illegal immigrants find it more difficult to secure employment and receive lower wages, thus finding it difficult to secure mortgage facilities. Painter et al. (2001) further show that educational attainment may be a 
key determinant of housing outcomes. This may be because individuals with lower educational status may be less competitive in the labour market thus earning lower income than their counterparts.

The foregoing highlights the importance of socioeconomic factors in determining housing tenure outcomes. Our modelling will therefore test for the impact of the key factors discussed. It is also important to note that a vast proportion of these analysis are done in the United States context using United States data. Nygaard (2011) makes a reasonable contribution towards a different geographical context- the UK. However, the analysis focuses on racial cohort variations, leaving a knowledge gap on the possibility of variations in the effects of socio-economic factors on migration generation in the UK. Our research aims to address this by testing the variation in the effects of key socio-economic factors on migration generations.

\section{Effects of location and housing characteristics}

Scholars also attribute housing tenure variation to locational and housing factors. Borjas (2002) appears to offer the first explicit articulation of a systematic variation of homeownership rates across cities, a perspective which was not widely stressed by previous literature. He attributes the metropolitan variation to the structure of housing market and regional differences in housing cost and includes a vector of almost 300 metropolitan area fixed effected in his model. His results show that there are differences in locational choices made by natives and immigrants, and these affect their homeownership choices.

Borjas 2002 further attributes housing tenure variation to the more micro-level effects such as local and neighbourhood factors, particularly revealing that the growth of ethnic enclaves in major cities increase the probability of homeownership for immigrants. Recent research also attributes homeownership outcomes to the proportion of immigrants in a neighbourhood, the dominant housing tenure in the neighbourhood (such as public housing, rental and homeownership), housing quality, crime rate, safety, services, infrastructure and housing deficiency in a particular neighbourhood (Zorlu et al. 2014; Hall and Greenman, 2013). Additionally, Skifter Andersen et al. (2016) analyse locational effects in European cities and also support the allusion that locational factors influence housing tenure outcomes. The study of Nygaard (2011) which is identified as making a key contribution to the subject area in the 
UK however fails to account for locational effects. We make an improvement on this by incorporating locational effects at regional level.

\section{Effects of individual, household and demographic attributes}

Individual, household and demographic attributes have also been identified as key factors influencing housing tenure and typically serve as the basis and context of housing tenure analysis. Borjas (2002) and Zorlu et al. (2014) identify individual tastes, preferences, social networks, household attributes and country of origin as key factors that impact housing tenure choices. For instance, Zorlu et al. (2014) reveal that Moroccans have a higher homeownership rate than Turkish immigrants in the Netherlands resulting from individual characteristics, household characteristics, family structure, marital status, parental background, neighbourhood factors, financial awareness and exposure, and their perception and attitude towards homeownership in their home country. However, their categorisation may be flawed because they classify all individuals who have identified themselves as Turkish as immigrants, thus ignoring the possibility that some of them may have been born in Morocco which makes them second-generation migrants.

Scholars (Goodman, 1990; Coulson, 1999; Nygaard, 2011; Zorlu et al. 2014; Skifter Andersen et al. 2016) also reveal that demographic factors such as gender, race, ethnicity and age influence housing tenure outcomes. Aslund (2005) specifically finds that households with male heads have lower homeownership probability, and Kuebler and Rugh (2013) observe a variation in homeownership differences between Whites, Asians, Mexicans and Cubans. Kuebler and Rugh (2013) however acknowledge that socio-economic effects may be stronger that demographic effect. It will therefore be worthy to compare these across migrant generations. A common trend in these studies is their dual classification (natives and immigrants/foreign-born and natives) which fails to account for the heterogeneity of secondgeneration migrants.

\section{Lifecycle Effects (natural and migration lifecycle)}

Clearly, scholars focus on socio-economic, locational, demographic, individual and household attributes as key determinants of housing choices. While most of these studies account for the impact of age (typically by controlling for age in their models) majority do 
not appear to highlight and explicitly articulate the fundamental role of the lifecycle stage of an individual in determining his/her key choices and life decision such as housing.

Classical economics literature suggest that individual circumstances, choices, consumption and savings decisions are a lifecycle function. The lifecycle theory, based on the classic of Modigliani and Brumberg (1954) suggests that an individual's lifecycle position (stage of life defined by age) is a key determinant for savings, consumption and other decisions (Mariger, 1987; Megboluge and Linneman, 1993; Tin, 2000; Wakefield, 2009). Housing tenure scholars however fail to explicitly account for the fundamental role of the lifecycle in their models. The application of this theory is vital for analysing housing tenure because its suggests that certain age cohorts have different propensities for certain outcomes (eg renting and owning) and this should be explicitly articulated in housing tenure research.

In conventional modelling, age is applied as an in-level variable, and in some other instances, the age variable is squared in order to account for the expected non-linear effect of age on housing tenure choice. While these may be valid application in terms of econometrics, they do not create the opportunity to test lifecycle effects. The research of Painter et al. (2002) attempts to close this gap by analysing the probability of being in age group 25-34 to own relative to rent and comparing this probability to those in age group 18-24, 35-44, 45-54, and 55-64. Suffice to state that while it is clear that they clearly apply the lifecycle theory, they do not make an explicit link to the lifecycle theory. Regardless, their results are consistent with theory- individuals' homeownership prospects increase as they advance in their lifecycle. Their results further reveal that the increase in the homeownership prospect slows down at the latter stages of the lifecycle. This age grouping appears appropriate- they exclude individuals below the age of 18 probably because individuals in this age group may be unable to make their personal housing decisions. However, they also exclude individuals aged over 65. We find no justification for this, thus in carrying out our analysis, we adopt the age classification in Painter et al. (2002) and include individuals that are over 64 years of age in order to account for the whole population.

It is still not clear if the lifecycle theory has an identical application to natives, firstgeneration and second-generation migrants, though descriptive evidence in (Figure 4) suggests that the lifecycle effects may vary across migration generations. We therefore 
employ empirical modelling to test for the variation of the lifecycle effects across migration generations.

Despite the fundamental role of the lifecycle effects in housing choices, decision and outcomes, we perceive that it may have a different application to the first-generation migrant cohort whose decisions transcend the natural lifecycle effects (age). We hypothesise that migration lifecycle (number of years spent in resident country) effects (as shown in Figure 5) may have a stronger impact in determining housing outcomes of first-generation migrants-a view that is hardly theoretically or empirically articulated in the literature.

Figure 5 reveals that the homeownership prospects increase as immigrants advance in the migration lifecycle, while rental tenure propensity diminishes. This further suggests that new immigrants are more likely to rent than to buy houses upon arrival in the destination country. New immigrants (regardless of their age) typically need a few years to settle down in the destination country and may find it difficult to access mortgage funding and other facilities due to a lack of credit history, security verification and other socio-economic challenges, thus making early homeownership difficult. This may also be the reason for the higher rental rates for immigrants in the early stages of the migration lifecycle. It can therefore be inferred that the natural lifecycle may have a stronger impact on natives and second-generation migrants than for the first-generation migrant; and the migration lifecycle may have stronger effects than the natural lifecycle for first-generation immigrants.

Some key studies (such as Coulson, 1999; Borjas, 2002) fail to account for the years spent in the resident country, while some scholars include some elements of the migration lifecycle in their models, however they articulate and apply it differently. For instance, Nygaard (2011) analyses year of entry into the UK as a cohort effect, thus only considering those who migrated between 1994 and 2006. While the cohort effect is a valid consideration, it does not capture the broad-ranging migration lifecycle effects and the results are not explained in this context either. Painter et al. (2002) also capture the years spent in the resident country, however their analysis does not contextualise the migration lifecycle effect.

The context and application of the migration lifecycle is important because it accounts for the years spent in the destination country, rather than merely cohort effect. Furthermore, the phrase "migration lifecycle" appears appropriate based on the fact that is has similar 
parameters and unit of measurement as the natural lifecycle ${ }^{6}$. Thus, while the natural lifecycle measures the number of years a person has lived on earth, the migration lifecycle captures the number of years a person has lived in a destination country (which are often different for the first-generation migrant cohort). We therefore aim to compare the migration lifecycle effect with the natural lifecycle effects along with other effects in order to identify the more prominent drivers of housing tenure outcomes for first-generation migrants.

Based on this review, it is clear that while socio-economic, demographic, sociocultural and locational factors appear to be the key focus of scholars in the study area, and the underlying lifecycle effects are typically not adequately recognised. Furthermore, the migration lifecycle effect is often not explicitly acknowledged or articulated. The lifecycle theory will therefore underpin our analysis, and the migration lifecycle effects will further serve as the basis of our analysis for the first-generation migrants.

While descriptive evidence may exist in respect to some aspects of the literature gaps highlighted, empirical evidence is mixed in the literature. Without rigorous empirical tests, predictions of theoretical models remain at best well-seasoned speculation, and not suitable to guide policy (Dustman et al., 2005), thus, this paper will provide empirical evidence revealing factors which may be driving the variation in housing outcomes for natives and non-natives in the UK using longitudinal data. The focus of this paper is private housing tenure outcomes ${ }^{7}$. The key reason for the exclusion of social/public housing tenure in our paper is that a vast majority of first-generation migrants are restricted by "no recourse to public funds" of interpretation.

Furthermore, the research design enables us to observe the extent to which second-generation migrants compare to natives or first-generation migrants and whether it is more appropriate to classify second-generation migrants as natives, migrants or as a separate unique cohort in terms of housing outcome.

Theoretically (and based on the descriptive evidence), it is expected that a distinct variation should exist in housing tenure patterns for natives and non-natives (first and second-

\footnotetext{
${ }^{6}$ Unit of measurement is the number of years and it captures the fact that a new life starts in the foreign country for many migrants, starting from scratch and embarking on building a new life

${ }^{7}$ Homeownership relative to rental

${ }^{8}$ Clause on visa issued implying lack of access to social/public housing (among other public benefits)
} 
generation migrants). Furthermore, while the natural lifecycle is expected to play a significant role in housing tenure patterns for natives and non-natives, the migration lifecycle is expected to play a significantly stronger (more prominent) role in influencing housing tenure patterns of first-generation migrants. In terms of expectation for second-generation migrants, it is tricky to form a specific expectation for their housing tenure pattern and the level of the homogeneity or heterogeneity relative to the housing tenure patterns of natives and firstgeneration migrants. Our analysis will offer better insight on this.

Housing for migrants is closely linked with the immigration policies and also the housing policies. While immigration policies largely concentrated on the entry issues, much less attention has been placed on integration policies for the migrants. Housing is a big part of integration issues. A good, desirable housing solution can go a long way in integrating a migrant's life outcome within the destination country. Dell'Olio (2004) discusses the general issue of immigrants' social integration in the EU with Italy and the UK as the focus areas. Drawing on the distinguishing features of immigration policy and immigrant policy, it highlights major problems related to housing policy and immigrants' social integration.

In the next section, we describe our empirical framework.

\section{Data and methods}

Data description

The UK Household Longitudinal Study (UKLS) data (covering the period of 2009-2016) is used for this analysis. The sample contains observations from 40,000 households every year and the dataset is presently the only publicly available database on immigrants in Britain thus well suited for this research. We use waves 1-7 (covering a period of 2009-2016) of the Understanding Society data for our analysis. The longitudinal sample is derived from an annual survey for all the households and individuals in the household throughout their life course.

The UKLS data is an extension of the British Household Panel Survey (BHPS) which ran from 1991 to 2008. This dataset has been used by several scholars (such as Benito, 2009; Koblyakova, Hutchison and Tiwari, 2014; Tumen and Zeydanli, 2014) to model pathways of 
individuals and households, and in some cases, to test lifecycle effects in the UK. According to the University of Essex (2017), the UKLS data is an extract from the Understanding Society Survey which is nationally representative survey of UK households which tracks individuals. It contains a household-level questionnaire and an individual questionnaire for each adult member of the household. This is the largest longitudinal study in the UK and provides crucial information for researchers and policy makers on the causes and consequences of change in peoples' lives. The data collection is continuous with people interviewed every year making provision to capture both short and long-term changes. Furthermore, it has national, regional and local data for all four countries in the UK (Scotland, Wales, Northern Ireland and England), and it covers all ethnic and immigrant groups which allows for comparison of the experiences of people in different places. It is multi-topic, conveying a range of social, economic, and behavioural factors, with questions covering family life, education, employment, and finance. Furthermore, the nature of the data, in terms of both the data collection process and the information available is similar to the US Panel Study of Income Dynamics (PSID), the Household Income and labour Dynamics Australia (HILDA), German Socio-Economic Panel (SOEP), and Survey of Family Income and Employment (SoFIE) in New Zealand.

Stratified and clustered sampling are combined in the sample design, with an equal probability sample of residential addresses for sample subjects in England, Wales and Scotland. At national level, the population is divided into mutually exclusive and exhaustive strata: each of the 12 regional geographical units having three occupational bands (total of 36 bands), and each of these occupational bands having three population bands, hence a total of 108 strata are created. The population is further divided into clusters of postcode sectors (Primary sampling Units) totalling 2640, and only a few clusters are randomly sampled ${ }^{9}$. Form each of the clusters, 18 addresses are selected using systematic random sampling. For the Northern Ireland component, unclustered systematic simple random sampling of 2,395 residential address drawn from the Land and Property Services Agency in Northern Ireland is adopted which suggests that every individual has an equal chance of selection in Northern Ireland.

\footnotetext{
${ }^{9}$ The random selection of clusters has been done to reduce cost of the survey, but it also creates sample bias, as some individuals have no chances of participation
} 
The stratified sampling increase representation of the sample of all the geographical regions, social classes and population densities, thus estimates are more precise than a simple random sample of the same size. However, clustering at the PSU level may be less precise in estimates and thus less precise than simple random sampling of the same size. Furthermore, combining the Northern Ireland component and the UK component of data may make selection probability of this sample approximately twice that of the $\mathrm{UK}^{10}$.

Another limitation associated with using the UKLS data is linked to the sample design of the Immigration Ethnic and Minority Boost (IEMB) component. This boost was collected to increase the representation of immigrants and ethnic minorities and in order to achieve this, 2,500 adult interviews were administered to five key target ethnic minority groups in identified areas of high concentration of ethnic minorities ${ }^{11}$. However, upon selection of a particular area, simple random sampling is conducted hence every individual has a $100 \%$ chance of selection within a given area which reduces selection bias at a micro level.

As shown in Table 1, a total of 273,460 individual private housing tenure choices are recorded from waves 1 to 7 . This large sample size is thus suitable for answering our research questions and other wide range of topics. The dataset is also suitable for the current study because of the variety of individual, household, socio-economic, demographic and locational factors it captures, as well as its longitudinal form which allows for cross sectional analysis, time series analysis and longitudinal study, thus offering cross sectional perspectives, while accounting for changes over time.

List of variables and description

As discussed in the literature review, models of the housing tenure choices and transition typically test for the effects of several factors which are often classified as individual and demographic (age, race gender, marital status, ethnicity), household (household size, number of children, number of dependent children), socio-economic (educational qualification, income, debt level, employment status, type of job, savings), housing and locational (number of bedrooms, type of property, neighbourhood, distance to place of work, UK region of location), and sociocultural factors (religion, English proficiency, beliefs and culture). Additionally, migration-related factors (migration status, reason for migration, country of

\footnotetext{
${ }^{10}$ This higher probability has the potential to bias UK wide estimates towards Norther Ireland

11 This selection is not random, hence bias is increased
} 
origin, years spent in destination country, migration status of parents) may be analysed for the first-generation migrants. However, for the purpose of this paper, the models used are set up using the conventional factors of influence which will serve as base models, while other factors will be incorporated at the later stages of the research. Table 1 provides the definition, summary statistics and transformation of the variables that we have used in the empirical investigation.

\section{[INSERT Table 1]}

\section{Methodology}

As stated earlier, our research question is: which factors are likely to increase and decrease the likelihood of homeownership and renting for natives and non-natives? This can typically be modelled as the conditional probability of tenure choice (conditional on a set of vector of unobserved characteristics " $x$ " of "homeownership" $y=1 . P(y=1 \mid x)$. Based on the assumption that $E(u \mid x)=0$, the zero conditional mean assumption holds, thus,

$$
P(y=1 \mid x)=E(y \mid x)
$$

The logit and probit models constrain values between 1 and 0 and the functions are nonlinear, requiring maximum likelihood estimation, since the effect of $\mathrm{x}$, will be non-linear. According to Train (2009), Dynamic Causal Modelling (DCM) must have finite number of alternatives, be exhaustive and mutually exclusive; and the models adopted are defined in terms of latent variable hence a latent variable approach:

$$
y_{i}^{*}=\mathbf{x}_{i}^{\prime} \boldsymbol{\beta}+e_{i}
$$

$y_{i}{ }^{*}$ is an unobserved latent variable thus it enables an observation of whether individuals are homeowners or not $\left(\mathrm{y}_{\mathrm{i}}\right)$ which in essence represents housing tenure. The values of " 1 " in homeownership and " 0 " in rented housing are determined by whether the outcome variable $\left(\mathrm{y}_{\mathrm{i}}{ }^{*}\right)$ crosses a threshold or not (threshold typically normalised to 0 ), negative values or " 0 " values of the latent variable would result in the observed variable $\mathrm{y}_{\mathrm{i}}$ being equal to " 0 ", while positive values are equal to " 1 " $\left(y_{i}=0\right.$ if $y_{i}^{*} \leq 0$ and $y_{i}=1$ if $\left.y_{i}^{*}>0\right)$. This implies that a little change in some of the observed characteristics $(\boldsymbol{x})$ and hence change in the latent variable may induce an individual to transit from rental to homeownership, while causing others to maintain their choice. $e_{i}$ captures the errors which are assumed to be independent of 
$x_{i}$ and symmetrically distributed around " 0 ". When two individuals have the same observed characteristics $(x)$, but different choices $\left(y_{i}\right)$ the difference will be determined by the error $\left(e_{i}\right)$ which is determined by the crossing of the threshold or not. Furthermore, cumulative distribution of the error term $\left(e_{i}\right)$ typically follows a normal or logistic distribution hence assuming an appropriate function for the errors can derive the probit and logit models.

For the purpose of this paper, the Probit model will be used to test the hypotheses. The Probit model is estimated through maximum likelihood estimation (MLE). The MLE produces $\beta$ estimates most likely to have resulted in the observed values of $(y)$, given the explanatory variables $(x)$, and where observations are assumed to be independent of each other. The likelihood function is the product of the individual probabilities for each outcome, with the $\log$ likelihood functions in the binary case:

$$
\text { Probit: } \ln L\left(\boldsymbol{\beta} \mid \mathbf{x}_{i}\right)=\sum_{i=1}^{n}\left[\left(1-y_{i}\right) \cdot \ln \left[1-\Phi\left(\mathbf{x}_{\mathbf{i}}^{\prime} \boldsymbol{\beta}\right)\right]+y_{i} \cdot \ln \Phi\left(\mathbf{x}_{\mathbf{i}}^{\prime} \boldsymbol{\beta}\right)\right]
$$

The marginal effects refer to the impact the explanatory variables have on the probability of being in homeownership relative to rental housing and since the estimation is non-linear, all the other explanatory variables need to be held at specific values (typically their means and also known as partial/marginal effect at the average):

$$
\frac{\partial p\left(\boldsymbol{\mu}_{\mathbf{x}}\right)}{\partial x_{j}}=\hat{\beta}_{j} g(\overline{\mathbf{x}} \hat{\boldsymbol{\beta}})
$$

$\mu_{x}$ represents the mean of the predictor variables $(x) ; g$ represents the Probit link function.

In the probit model, there are no directly comparable r-squared measure as used in OLS but there are various pseudo r-squared measures. Considering that pseudo r-squared is not comparable to the OLS version, models with pseudo r-squared values between 0.2 and 0.4 are often considered good fit (Hensher and Johnson, 1981).

In setting out the model, we anticipate certain sources of biases which may negatively impact our models. A key issue is heteroscedasticity and non-normality in the error term. Heteroskedasticity is the possibility that the size of error term $\left(u_{i}\right)$ differs across values of a predictor variable $\left(x_{i}\right)$. It may also be referred to as the circumstances in which the variability of a variable is unequal across the range of values of another variable that predicts it. It means 
that the variance of the error term of the predictor variables $\left(x_{i}\right)$ is a function of $x_{i}$ \{ Var $\left.\left(e_{i} \mid x_{i}\right)=f\left(x_{i}\right)\right\}$. There are usually concerns about the non-normality of the errors (e) in the latent variable which may suggest that the probability would not have a probit form and the estimated coefficient may be inconsistent. Wooldridge (2013) however argues that even consistent estimates of the coefficients will not capture the magnitude of the marginal effects. Given that the probabilities are conditional on the $x$ variables, it is highly likely that the unobserved latent variable will be heteroskedastic. Thus, the "robust" option is applied in the model to account for heteroskedasticity. However, while the robust option may correct heteroskedasticity in OLS regression, it may not adjust for heteroskedasticity in the latent model and this may lead to inconsistent estimates. Despite heteroskedasticity being common in cross sectional data, it is an issue that is usually ignored (partly due to the fact that latent variables are never observed). Given that scholars have hardly come to a consensus regarding the best solution, it is often ignored.

Our estimation equations is specified as follows:

General Population:

$\operatorname{Pr}($ Ownrent $\left.)=1 \mid X_{1} X_{2} \ldots X_{14}\right)=\beta_{0}+\beta_{1}$ age $+\beta_{2}$ household size $+\beta_{3}$ marital status $+\beta_{4}$ gender + $\beta_{5}$ educational qualification $+\beta_{6}$ employment status $+\beta_{7}$ regional location $+\beta_{8}$ race $+\beta_{9}$ urban $d$ welling $+\beta_{10 d i s a b i l i t y}+\beta_{11}$ living with spouse $+\beta_{12}$ subjective financial well-being + $\beta_{13}$ expectation to change accommodation $+\beta_{14 \text { wave }}$

First-generation migrants:

$\operatorname{Pr}($ Ownrent $\left.)=1 \mid X_{1} X_{2} \ldots X_{15}\right)=\beta_{0}+\beta_{1}$ age $+\underline{\beta_{2} \text { migration lifecycle }}+\beta_{3}$ household size $+\beta_{4}$ marital status $+\beta_{5}$ gender $+\beta_{6}$ educational qualification $+\beta_{7}$ employment status $+\beta_{8}$ regional location $+\beta_{9}$ race $+\beta_{10 \text { urban }} d$ welling $+\beta_{11}$ disability $+\beta_{12}$ living with spouse $+\beta_{13 \text { subjective financial well-being }+\beta_{14} \text { expectation to change }}$ accommodation $+\beta_{15 \text { wave }}$

\section{Results and Analysis}

It is important to observe significant effects of native's attributes and migration generations that are associated with homeownership prospects. To consider this, we analyse migration 
generational effects, first by the region, and then by their income class.

\section{[INSERT TABLE 2]}

We develop a baseline model and replicate the model specification in 12 models based on the 12 regional geographical units in Britain. Our key dependent variable is a categorical variable that captures the traditional immigration generations. The hold-out category is "natives", thus we can observe how being a second-generation or first-generation immigrant affects the prospects of homeownership. The regional classification is important because previous research (Drake 1995; Koblyakova et al. 2014) provide some evidence of regional variations in the UK housing market. Additionally, studies such as Muller and Espenhade (1985), Ley and Tuchener (1999) and Saiz, (2003 and 2007) suggest that the housing markets in migrant gateway and destination cities may be distinct, thus this regional analysis facilitates an exploration of the uniqueness of London, which according to Gidley (2011), is the main UK immigrant gateway and destination city.

The results in Table 2 show both positive and negative prospects of homeownership for first and second-generation immigrants compared to natives, suggesting mixed effects on regional basis. The first-generation immigrants can be observed to have lower homeownership prospects in all British regions, and these effects are statistically significant across the regions apart from North-east England, thus confirming our hypothesis that being a first-generation immigrant negatively affects homeownership prospects in the UK regions. Conversely, apart from London where the effect is statistically significant, these effects are statistically insignificant in all other regions for second-generation migrants. This suggests that being a second-generation immigrant (compared to natives) does not particularly affect homeownership prospects (apart from London residents). Additionally, we also observe that London is unique in several ways: first, the second-generational effect is only statistically significant in London; second, the first-generational effect, though statistically significant in majority of the regions, has a more robust effect in London; and third, the model fit for London appears to be the strongest among all regions. These lend empirical support to the notion that London has a significantly unique housing pattern, and this can be a subject for further study. Furthermore, the higher magnitude of the negative effect of being a firstgeneration migrant may also be an indication of affordability constraints, which is severe in London. 
To observe a possible variation across income categories, we also replicate the baseline model specification for six income-based models. We develop a simple categorisation of income classes based on the basic ${ }^{12}$ and higher rate ${ }^{13}$ of the UK annual taxable income bands ( $£ 11,850$ to $£ 150,000$ annual income). Specifically, we categorise Group 1 as households with a net monthly income between $£ 1,000$ and $£ 2,000$, Group 2 as households who earn $£ 2,001$ to $£ 3,000$, and Group 3 as households earning between $£ 3,001$ and $£ 4,000$.

Furthermore, households earning between $£ 4,001$ and $£ 5,000$ are classified in Group 4, while households earning between $£ 5,001$ and $£ 6,000$, and $£ 6,000$ to $£ 12,500$ are classified as Group 5 and Group 6 respectively. This enables us to observe if natives and non-natives differ in housing tenure outcomes despite being in similar economic classes.

\section{[INSERT TABLE 3]}

Table 3 reveals that first-generation immigrants have significantly lower homeownership prospects compared to other migration cohorts in the same income group. It can be further observed that these effects are of higher magnitude in the lower income categories (particularly Groups 1,2 and 3) suggesting that an upward transition in income class may increase the homeownership prospects of first-generation immigrants. It can also be observed that second-generation immigrants have higher homeownership prospects in most income classes (with the exception in Groups 4 and 5). These effects are however not statistically significant in most of the income classes in relation to natives, suggesting that there may be no significant differences between second-generation immigrants and natives in terms of their housing tenure outcomes.

Having established these key variations, we go on to expand the models and attempt different specifications.

Table 4 shows marginal effects for the baseline models. Model 1 shows the baseline specification. In model 2, we add locational fixed effects (regions in the UK) to control for locational unobserved heterogeneity. In model 3, we add time fixed effects to control for any temporal unobservables (waves of the surveys) ${ }^{14}$. And in the model 4 , we add both locational

\footnotetext{
${ }^{12}$ Earning an annual income between $£ 11,850$ and $£ 46,350$

${ }^{13}$ Earning an annual income between $£ 46,351$ and $£ 150,000$

${ }^{14}$ All our key models (Tables 4-7) have time fixed effects (apart from the Models in Table 3 columns 1 and 2 where we exclude the waves vector as an experiment). By accounting for time-fixed effects based on the waves in which the data was collected, we take advantage of the longitudinal nature of the data.
} 
and temporal fixed effects. One of our key goal is to find results that are consistent across all four models i.e. if we are able to find consistency in parameter estimates after controlling for unobserved heterogeneities. As evident from the table 4, the results are robust to this concern, when we compare across the columns. The goodness of fit is also reasonable, given the earlier point made on probit reporting lower goodness of fit.

\section{[INSERT TABLE 4]}

The interpretation of the marginal effects can be performed based on equation 4 i.e. 1 unit change in $x$ increases homeownership ( $y$ ) probability by the coefficient, holding all other factors constant at a given value. This implies that the probability of homeownership changes by beta $(\beta)$ as $x$ changes. Using table 4 (Model 1), for instance, the results suggest that moving from being in age group 35-44 increases homeownership probability by 0.021 (2.1\%) compared to being in the age group less than 25 years, holding other factors constant. Similarly, being a male decreases the probability of homeownership by $0.008(0.8 \%)$; while being from a household of two individuals increase homeownership probability by 0.023 (2.3\%), compared to a single individual household. Compared to the outcome for Whites, all other races tend to have negative feedback effect on homeownership rate. Living with spouse improves the probability of owning a home significantly.

\section{[INSERT TABLE 5]}

However, in Table 4, we have tested the hypotheses for the full sample. In Table 5 , we take the best specification of model 4 in Table 4 and test the hypotheses for natives, secondgenerations and first-generation migrants separately. There are several interesting findings coming out of Table 5. The results appear to be consistent with the lifecycle theoryhomeownership prospect increases for natives, first-generation and second-generation migrants. The magnitude of the effect of the factors tested are higher for the secondgeneration migrants (compared to those of natives). These appear to be much higher for the first-generation compared to natives and first-generation compared to second-generation. While the lifecyle effect for natives (model 2) and second-generation mgirants (model 3) are similar to the full sample model (model 1), there are much higher magnitude of influence for first-generation migrants - this underscores the importance of a heterogenous model, particularly when first-generation migrants are involved. Models that do not control for heterogeneity may be misleading for first-generation migrants. Effects of factors on second- 
generation appears similar to natives, than to first-generation, implying that secondgeneration migrants in Britain are similar to natives than to their parents which may indicate less barriers to assimilation. This appears to be different from research (such as Keeley, 2009) which find that assimilation is slower for second-generation migrants in terms of education. In terms of gender, women are slightly more likely to own than rent - this effect appear to be stronger for first generaiton migrants (significant in full-sample model, but insignificant for natives and second-generation migrants). The higher probability of women to own compared to renting for natives, first-generation and seocnd generation migrants is consistent with the findings of Aslund (2005).

\section{[INSERT TABLE 6]}

In Table 6, we further examine the lifecycle effects on the housing outcome of the firstgeneration migrant cohort. Specifically, we try to find the effects of the migration lifecyle in Table 6 column 2 and compare the results with those obtained in Table 5 column $4^{15}$. The results reveal that immigrants' homeownership prospects increase by the number of years they have spent in Britain and this is statistically significant. It is also noteworthy that the migration lifecycle effect is much stronger than the natural lifecycle effect, suggesting that the number of years spent in the destination country may be a stronger influence on the housing outcomes of first-generation migrants. This is supported by the significant increase in the model's goodness of fit (Psuedo $\mathrm{r}^{2}$ ) when the migration lifecyle is accounted for in the model. Furthermore, it can be observed that the age effect decreases significantly after the incorporation of the migration lifecycle, further supporting the allusion that the lifecycle effects may be an insufficient basis of modelling the housing outcomes for the firstgeneration migrants.

\section{[INSERT TABLE 7]}

In Table 7, we use the same model specifications as in Table 6, however the natural and migration lifecycle variables are callibrated in 10-year intervals in order to further observe the

\footnotetext{
${ }^{15}$ Table 6 column 1 is a direct replication of Table 5 column 4, however we combine the hitherto binary variables for age in a categorical variable (and do the same for the migration lifecycle) in order to have a more unified basis for comparison.
} 
actual "lifecycle" effects. The results in Table 7 column 2 suggest that a 10-year increase in number of years spent in Britain has very significant effects on the immigrants' homeowership prospects. It further suggests that the most significant prospects of homeownership are in the first three stages of the migration lifecycle and these effects drastically reduce as immigrants advance in their migration lifecourse.

\section{Summary and Concluding Remarks}

In particular, summary of the findings for specific attributes are as follows:

Educational qualification: we find varying effects for first-generation migrants compared to second-generation and natives. Specifically, having a degree increases homeownership prospects for natives and second-generation, while it has the adverse effect on first-generation migrants.

Race: For all observations, being White increases homeownership prospects and this is largely statistically significant. Models controlling for specific sample however show variations by migrant cohort - race is a stronger predictor for natives than for secondgeneration and least of a factor for first-generation migrants.

Urban dweller: being an urban dweller decreases homeownership prospects for second and first-generation migrants. This may be an indication of affordability in most UK urban areas which may be linked with high property prices.

Mobility (expecting to change acommodation): housing mobility plays a stronger role for the first-generation migrants than for the second-generation non-natives and natives.

Locational (Regional) Factors- living in London: When we control for the regional effects, we find that living in London decreases homeowership prospects for the first-generation nonnatives and natives, but being in the regions of North East, South East, South West and Wales decreases homeownership prospects for the second-generation migrants compared to living in London.

Migration lifecycle: We find that immigrants' homeowernship prospects increase as they advance in their migration lifecyle (i.e. years spent in Britain). We further observe that the 
migration lifecycle may be a better predictor of housing tenure outcomes than the natural lifecycle (i.e. age) for the first-generation migrants.

In general, our findings suggest a strong and statistically significant variation in housing tenure drivers and outcomes for the natives and non-natives. The second-generation nonnatives appear to have similar housing tenure and outcomes to natives than to their parents (the first-generation migrants). Model controlling for unobserved heetrogeneity and specific samples, offer more robust insights, and may offer better prediction for heterogenous, mised societies like in modern Britain.

Migration has perhaps been the most consistent long-run trend, which has clearly intensified in recent years. The drivers and determinants of migration both in the destination and origin country differ significantly. One of the key area of policy analysis is housing outcome, which is linked to employment outcome. We analyse the British context in this paper. Using a large longitudinal dataset, our results point to several significant factors.

In terms of the housing context, instead of focusing solely on migrants, we have analysed the outcomes with comparison to the native counterparts. This has allowed us to showcase the varying nature of housing tenure outcomes for natives and non-natives. This is important to study as one of the most politically contentious and recent rhetoric is around the frequently claimed effect of immigration having detrimental effects on the already broken housing market with burgeoning demand in the face to lack of supply and worsening housing affordability. The empirical evidence is not strong and not backed by rigorous methods. The anecdotal nature of the debate is unhelpful for any meaningful and objective policy formulation and often can lead to nationalistic movements and sentiments that go against all the great outcomes of a globalised world. For targeted policy-making that may help with the housing outcomes for both native and migrant groups, it is important to understand the real effects that migration has caused. This study, with its limitations, shades light on this important policy area.

In this study, our analysis is built on a strong longitudinal evidence and robust methodology using probabilistic models. The probability models for tenure reveal significant variation in the outcomes which are robust to several econometric specification. The findings of this analysis can usefully contribute to policy formulations in terms of creating more equitable housing pathways. Migration adds to economic performance, especially skilled migration and 
migration that complements and fills the gaps in the skillset and employment requirements in the destination country. Appropriate policies can go a long way in facilitating the benefits of migration to add to the economic performance. Not only the economic performance, but also it is important for social cohesion and better integration. Poor and suboptimal housing outcomes can affect many other aspects of life - employment, health and wellbeing. We hope to continue the current study to analyse the Migration-related effects in more detail, decimal calibration testing and specific policy impacts over the last few decades. 


\section{References}

Åslund, O., 2005. "Now and forever? Initial and subsequent location choices of immigrants", Regional Science and Urban Economics, 35(2), pp.141-165.

Auspurg, K., Schneck, A. and Hinz, T., 2018. "Closed doors everywhere? A meta-analysis of field experiments on ethnic discrimination in rental housing markets", Journal of Ethnic and Migration Studies, 1-20.

Behtoui, A. and Olsson, E., 2014. "The Performance of early age Migrants in Education and the Labour Market: a comparison of Bosnia Herzegovinians, Chileans and Somalis in Sweden", Journal of ethnic and migration studies, 40(5), pp.778-795.

Benito, A., 2009. "Who withdraws housing equity and why?” Economica, 76(301), pp.51-70.

Borjas, G.J., 2002. "Homeownership in the Immigrant Population”, Journal of Urban Economics 52(3), pp.448-476

Cangiano, A, 2018. "The Impact of Migration on UK Population Growth", The Migration Observatory, University of Oxford, Accessed 18 August 2018. https://migrationobservatory.ox.ac.uk/resources/briefings/the-impact-of-migration-on-ukpopulation-growth/.

Carlsson, M. and Eriksson, S., 2015, "Ethnic Discrimination in the London Market for Shared Housing, Journal of Ethnic and Migration Studies, 41(8), pp.1276-1301.

Coulson, N.E., 1999. "Why are Hispanic-and Asian-American Homeownership Rates so low? Immigration and other factors", Journal of Urban Economics 45(2), pp.209-227.

Dell'Olio, F., 2004. "Immigration and Immigrant Policy in Italy and the UK: is housing policy a barrier to a common approach towards immigration in the EU?", Journal of Ethnic and Migration Studies, 30(1), pp.107-128.

Drake, L., 1995. Testing for convergence between UK regional house prices. Regional Studies, 29(4), pp.357-366.

Dustmann, C., Fabbri, F. and Preston, I., 2005. "The Impact of Immigration on the British Labour Market”, The Economic Journal, 115(507), F324-F341. 
Gidley, B., 2011. Migrants in London: policy challenges, The Migration Observatory, University of Oxford, Accessed 11 November 2018.

https://migrationobservatory.ox.ac.uk/resources/primers/migrants-in-london-policychallenges/

Goodman, A.C., 1990. "Demographics of Individual Housing Demand”, Regional Science and Urban Economics, 20(1), pp.83-102.

Gyourko, J., Linneman, P. and Wachter, S., 1999. Analyzing the relationships among race, wealth, and home ownership in America, Journal of Housing Economics, 8(2), pp.63-89.

Hall, M. and Greenman, E., 2013. "Housing and Neighbourhood Quality among undocumented Mexican and Central American Immigrants”, Social Science Research 42(6), pp.1712-1725.

Hensher, D.A. and Johnson, L.W., 1981. Applied discrete-choice modelling, Abingdon, NY, Routledge.

Keely, B., 2009. "International Migration: the human face of globalization”. UK: OECD Insights, pp1-167.

Koblyakova, A., Hutchison, N. and Tiwari, P., 2014. "Regional differences in Mortgage Demand and Mortgage Instrument Choice in the UK”, Regional Studies, 48(9), pp.14991513.

Kuebler, M. and Rugh, J.S., 2013. "New evidence on racial and ethnic disparities in homeownership in the United States from 2001 to 2010”. Social Science Research, 42(5), pp.1357-1374.

Ihlanfeldt, K.R. and Martinez-Vazquez, J., 1986. “Alternative value estimates of owneroccupied housing: evidence on sample selection bias and systematic errors". Journal of Urban Economics, 20(3), pp.356-369.

Ley, D. and Tutchener, J., 2001. "Immigration, globalisation and house prices in Canada's gateway cities”. Housing Studies, 16(2), pp.199-223.

Lindley, J., 2006. “The Over-Education of UK Immigrants: Evidence from the Labour Force 
Survey", Working Paper, Department of Economics, University of Sheffield, ISSN 17498368.

Mariger, R., 1987. “A Life-Cycle Consumption Model with Liquidity Constraints: theory and empirical results", Econometrica, pp.552-557.

Megbolugbe I. and Linneman, P., 1993. "Homeownership". Urban Studies 30 (4/5), pp.659682.

Modigliani, F. and Brumberg, R., 1954. "Utility Analysis and the Consumption Function: an interpretation of cross-section data", Franco Modigliani 1, pp388-436.

Muller, T \& Espenhade, T, [1985], The Fourth Wave, Urban Institute Press, Washington DC. Nygaard, C., 2011.” International Migration, Housing Demand and Access to Homeownership in the UK", Urban Studies, 48(11), pp.2211-2229.

OECD, 2017. "International Migration Outlook 2017”, 41st edition, Paris, OECD Publishing. Painter, G., Gabriel, S. and Myers, D., 2001. "Race, Immigrant Status, and Housing Tenure Choice", Journal of Urban Economics, 49(1), pp.150-167.

Rienzo, C. and Vargas-Silva, C., 2017. "Migrants in the UK: An Overview", The Migration Observatory, University of Oxford. Accessed 6 September 2018. https://migrationobservatory.ox.ac.uk/resources/briefings/migrants-in-the-uk-an-overview/.

Rosenthal, S.S., Duca, J.V. and Gabriel, S.A., 1991. "Credit rationing and the demand for owner-occupied housing", Journal of Urban Economics, 30(1), pp.48-63.

Rumbaut, R.G., 2004. “Ages, Life Stages, and Generational Cohorts: decomposing the immigrant first and second-generations in the United States", International Migration Review 38(3), pp.1160-1205.

Saiz, A., 2007. "Immigration and housing rents in American Cities". Journal of urban economics, 61(2), pp.345-371.

Saiz, A., 2003. "Room in the kitchen for the melting pot: Immigration and rental prices". The Review of Economics and Statistics, 85(3), pp.502-521.

Skifter Andersen, H., Andersson, R., Wessel, T. and Vilkama, K., 2016. “The Impact of 
Housing Policies and Housing Markets on Ethnic Spatial Segregation: comparing the capital cities of four Nordic welfare states”, International Journal of Housing Policy, 16(1), 1-30.

Sillitoe, K., and P. H. White. "Ethnic Group and the British Census: The Search for a Question", Journal of the Royal Statistical Society, Series A (Statistics in Society) 155, 1 (1992), pp.141-63.

The Migration Observatory, 2016. "What would UK immigration policy look like after Brexit?". Commentary, The Migration Observatory, University of Oxford, Accessed 11 November 2018. https://migrationobservatory.ox.ac.uk/resources/commentaries/ukimmigration-policy-look-like-brexit/

The Migration Observatory, 2016. "Project Unclear: uncertainty, Brexit and migration". Commentary, The Migration Observatory, University of Oxford, Accessed 11 November 2018. https://migrationobservatory.ox.ac.uk/resources/commentaries/project-unclearuncertainty-brexit-and-migration/

Tin, J., 2000. "Life-cycle Hypothesis, Propensities to save, and Demand for Financial Assets", Journal of Economics and Finance, 24(2), pp.110-121.

Train, K, 2009. “Discrete Choice Methods with Simulation. Second Edition”. New York, Cambridge University Press.

Tumen, S. and Zeydanli, T., 2014. "Day-of-the-week effects in subjective well-being: does selectivity matter?”, Social Indicators Research, 119(1), pp.139-162.

University of Essex, 2017. Understanding Society: Wave 1-7, 2009- 2016, Institute for Social and Economic Research, NatCen Social Research and Kantar Public, 9th Edition, Colchester, Essex: UK.

Vargas-Silva, C., 2017. "Migrants and in the UK: Experiences and Impacts", The Migration Observatory, University of Oxford. Accessed 6 September 2018

<https://migrationobservatory.ox.ac.uk/resources/briefings/migrants-and-housing-in-the-ukexperiences-and-impacts/.

Wakefield, M.J., 2009. "Consumption and saving decisions in the face of choices about housing and pensions", Doctoral dissertation, University College London. 
Wooldridge, J. (2013). “Introductory Econometrics: A Modern Approach”, Fifth Edition, Canada, South Western Cengage Learning.

Zorlu, A., Mulder, C.H. and Van Gaalen, R., 2014. "Ethnic Disparities in the Transition to Home Ownership", Journal of Housing Economics, 26, pp.151-163.

Figure 1: Top 10 Countries of Origin of British Migrants (\% of total Migrant stock)

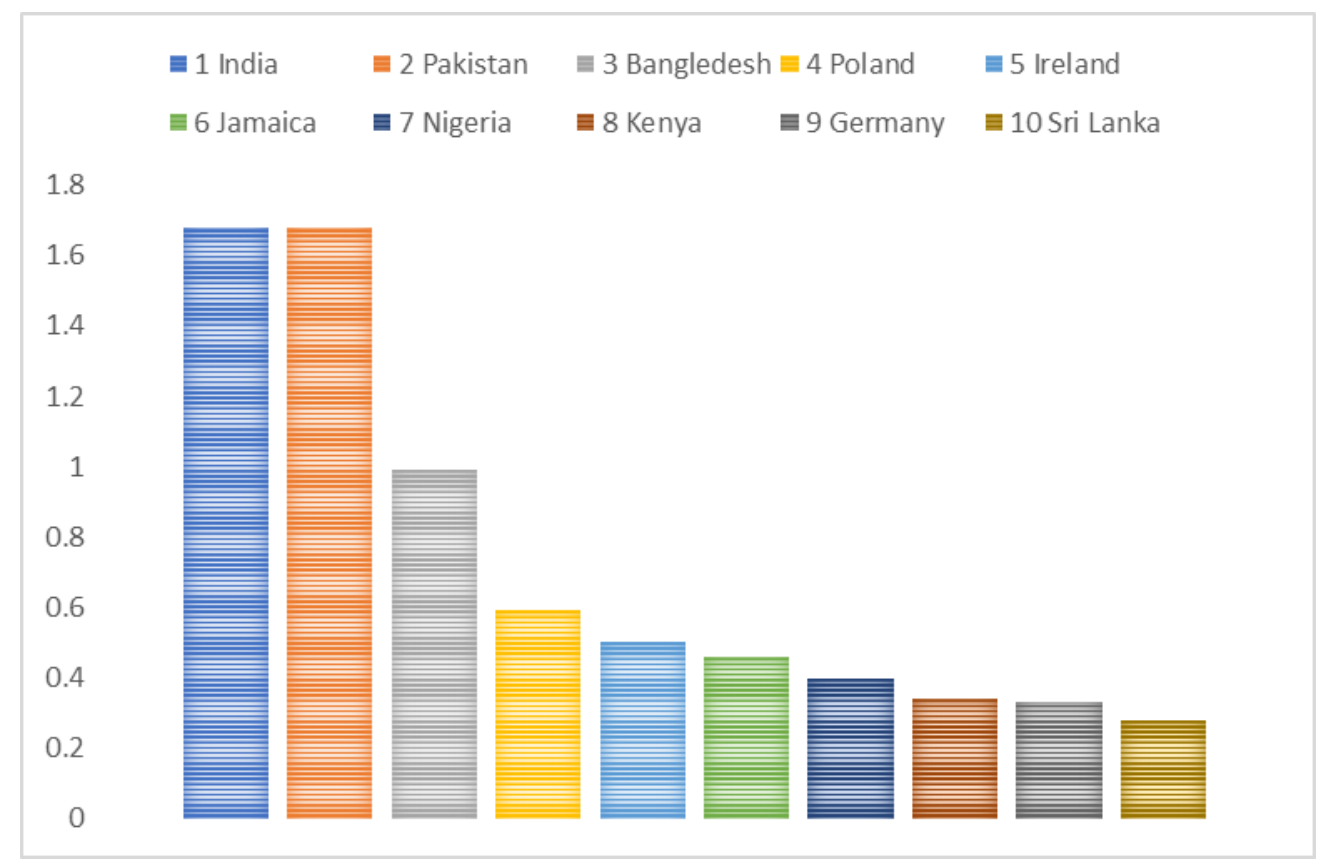

Source: University of Essex, 2017.

Figure 2: Homeownership/Rental Outcomes in Britain

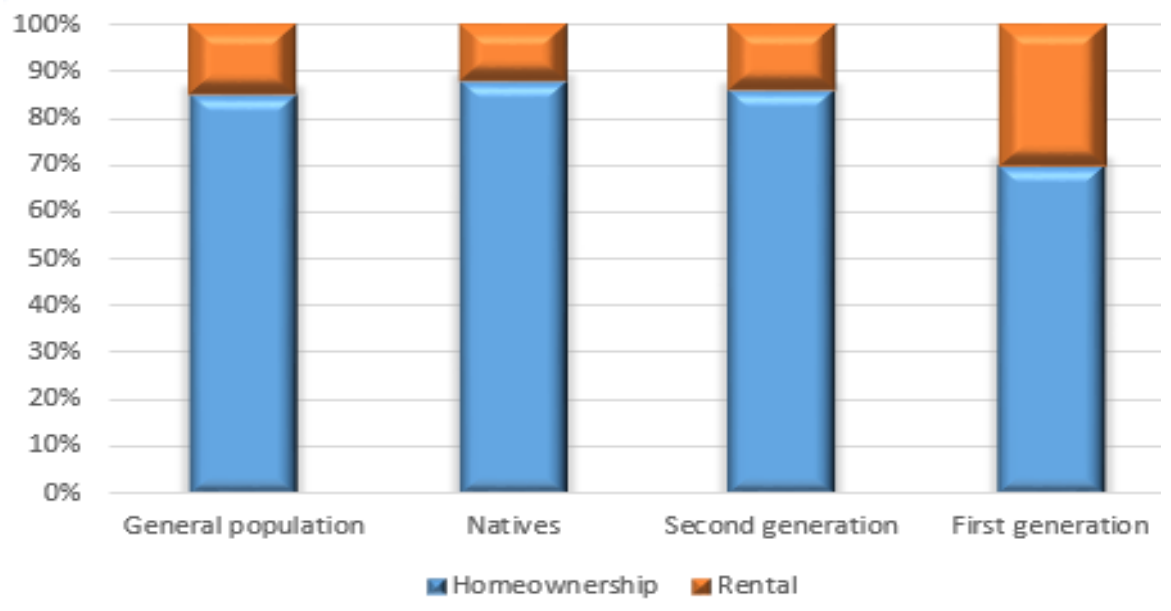

Source: University of Essex, 2017. 
Figure 3: Housing Tenure (Homeownership to Rental) Outcomes for the Top 10 Countries of Origin of British Migrants

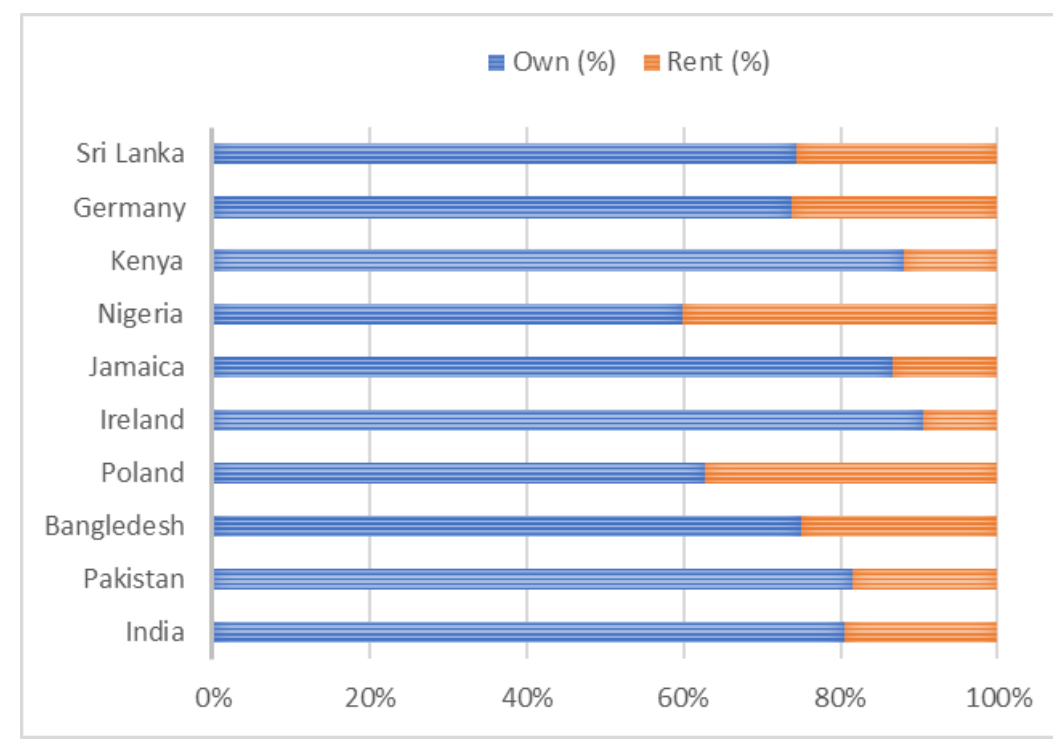

Source: University of Essex, 2017.

Figure 4: Lifecycle Effects on Housing Tenure Outcomes of Natives and non-natives in Britain

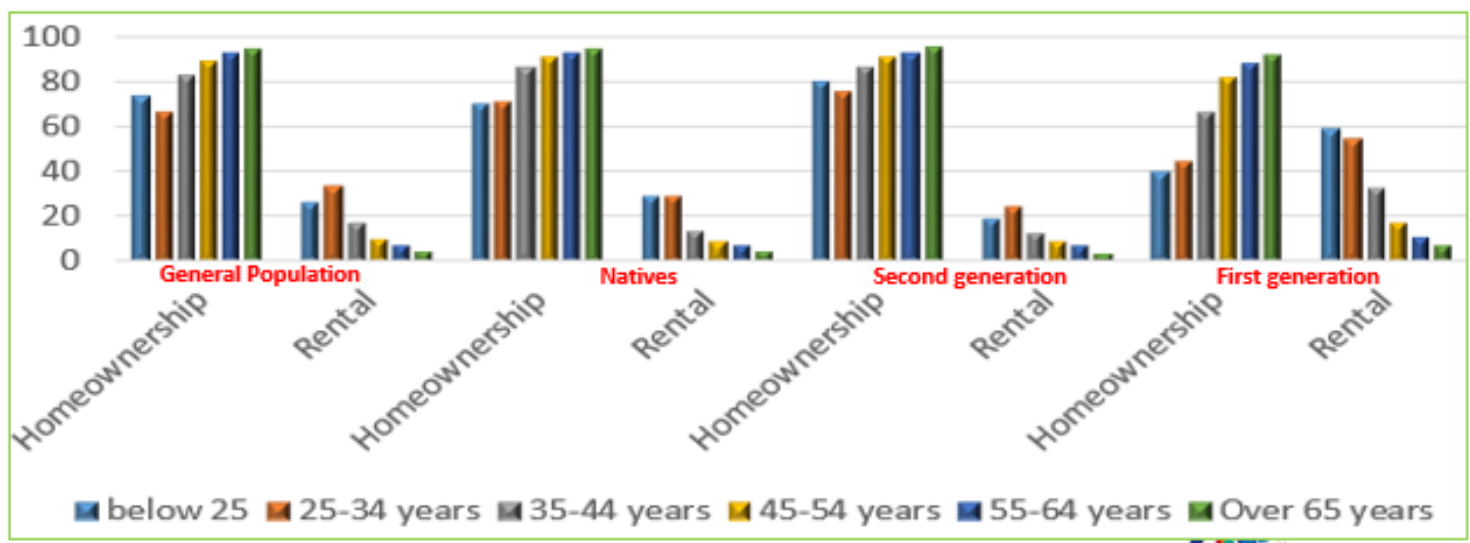

Source: University of Essex, 2017. 
Figure 5: Accommodation of Foreign-born by Migration Lifecycle (time spent in the UK)

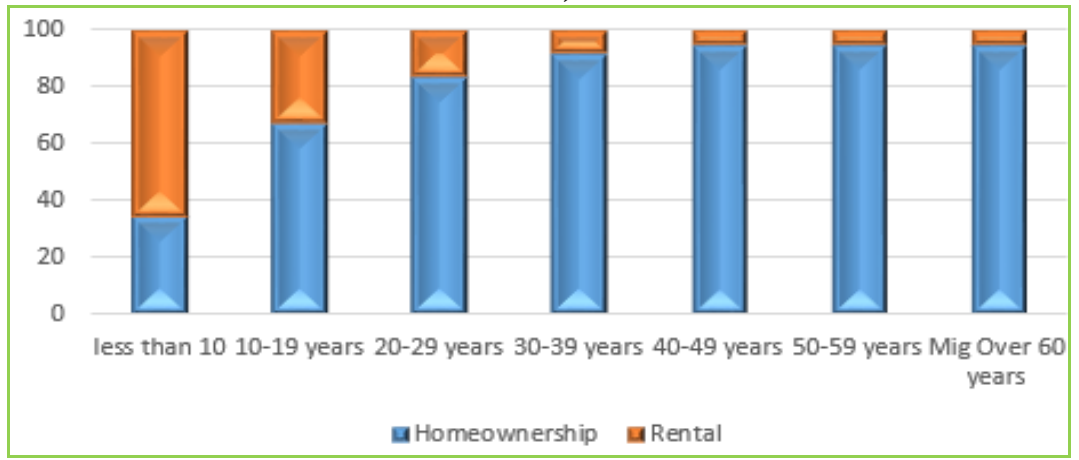

Source: University of Essex, 2017. 
Table 1: Summary Statistics

\begin{tabular}{|c|c|c|c|c|c|}
\hline Variable & Variable name & Variable Description & $\mathbf{N}$ & Mean & SD \\
\hline Homeownership & Homeownership & $\begin{array}{l}\text { Binary variable } 1=\text { Homeownership; } 0=\text { rental (indicating if the individual owns } \\
\text { or rents) }\end{array}$ & 273460 & 0.847 & 0.360 \\
\hline \multirow{8}{*}{$\stackrel{\infty}{<}$} & Age & Continuous variable: indicating the age of the individual & 333739 & 47.125 & 18.557 \\
\hline & Age below 25 years & Binary variable: $1=$ if individual is below 25 years; $0=$ otherwise & 333739 & 0.139 & 0.346 \\
\hline & 25-34 years & Binary variable: $1=$ if individual is $25-34$ years; $0=$ otherwise & 333739 & 0.148 & 0.355 \\
\hline & $35-44$ years & Binary variable: $1=$ if individual is $35-44$ years; $0=$ otherwise & 333739 & 0.179 & 0.383 \\
\hline & $45-54$ years & Binary variable: $1=$ if individual is $45-54$ years; $0=$ otherwise & 333739 & 0.180 & 0.384 \\
\hline & $55-64$ years & Binary variable: $1=$ if individual is $55-64$ years; $0=$ otherwise & 333739 & 0.150 & 0.357 \\
\hline & Over 65 years & Binary variable: $1=$ if individual is over 65 years; $0=$ otherwise & 333739 & 0.204 & 0.403 \\
\hline & $\begin{array}{l}\text { Lifecycle } \\
\text { (calibrated) }\end{array}$ & $\begin{array}{l}\text { Categorical variable: } 1=\text { below } 25 \text { years; } 2=25-34 \text { years; } 3=35-44 \text { years; } 4=45-54 \\
\text { years; } 5=55-64 \text { years; } 6=\text { over } 65 \text { years }\end{array}$ & 333739 & 3.667 & 1.696 \\
\hline \multirow{8}{*}{ 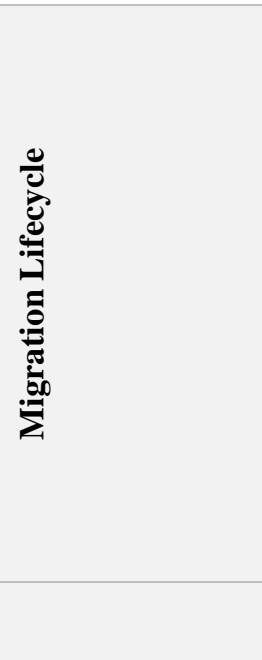 } & $\begin{array}{l}\text { Migrated less than } \\
10 \text { years ago }\end{array}$ & Binary variable: $1=$ if individual migrated less than 10 years ago; $0=$ otherwise & 51131 & 0.264 & 0.441 \\
\hline & $10-19$ years ago & Binary variable: $1=$ if individual migrated $10-19$ years ago; $0=$ otherwise & 51131 & 0.257 & 0.438 \\
\hline & $20-29$ years ago & Binary variable: $1=$ if individual migrated $20-29$ years ago; $0=$ otherwise & 51131 & 0.143 & 0.350 \\
\hline & $30-39$ years ago & Binary variable: $1=$ if individual migrated $30-39$ years ago; $0=$ otherwise & 51131 & 0.114 & 0.318 \\
\hline & $40-49$ years ago & Binary variable: $1=$ if individual migrated $40-49$ years ago; $0=$ otherwise & 51131 & 0.123 & 0.328 \\
\hline & $50-59$ years ago & Binary variable: $1=$ if individual migrated $50-59$ years ago; $0=$ otherwise & 51131 & 0.074 & 0.261 \\
\hline & Over 60 years ago & Binary variable: $1=$ if individual migrated over 60 years ago; $0=$ otherwise & 51131 & 0.026 & 0.441 \\
\hline & $\begin{array}{l}\text { Migration Lifecycle } \\
\text { (calibrated) }\end{array}$ & $\begin{array}{l}\text { Categorical variable: } 1=\text { less than } 10 \text { years ago; } 2=10-19 \text { years ago; } 3=20-29 \\
\text { years; } 4=30-39 \text { years; } 5=40-49 \text { years; } 6=50-59 ; 7=\text { over } 60 \text { years ago }\end{array}$ & 51131 & 2.898 & 1.1 .726 \\
\hline
\end{tabular}




\begin{tabular}{|c|c|c|c|c|c|}
\hline \multirow{6}{*}{ 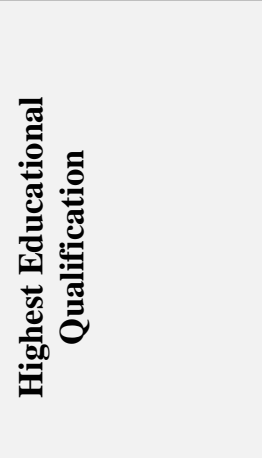 } & No qualification & Binary variable: $1=$ if individual has no qualification; $0=$ otherwise & 329611 & 0.144 & 0.351 \\
\hline & A-level & Binary variable: $1=$ if highest qualification is $\mathrm{A}$-level; $0=$ otherwise & 329611 & 0.210 & 0.407 \\
\hline & GCSE & Binary variable: $1=$ if highest qualification is GCSE; $0=$ otherwise & 329611 & 0.209 & 0.407 \\
\hline & Other higher degree & Binary variable: $1=$ if highest qualification is other degree; $0=$ otherwise & 329611 & 0.113 & 0.317 \\
\hline & Other qualification & Binary variable: $1=$ if highest qualification is other qualification; $0=$ otherwise & 329611 & 0.096 & 0.294 \\
\hline & Degree & Binary variable: $1=$ if highest qualification is first degree; $0=$ otherwise & 329611 & 0.228 & 0.420 \\
\hline Gender & Male & Binary variable: $1=$ if individual is male; $0=$ female & 333770 & 0.460 & 0.498 \\
\hline Disabled & Disabled & Binary variable: $1=$ if individual has a disability; $0=$ otherwise & 334403 & 0.341 & 0.474 \\
\hline \multirow{3}{*}{ 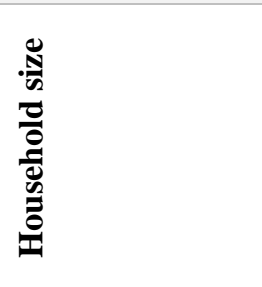 } & $\begin{array}{l}\text { Single individual } \\
\text { household }\end{array}$ & Binary variable: $1=$ if household has a single family member; $0=$ otherwise & 333773 & 0.141 & 0.348 \\
\hline & $\begin{array}{l}\text { Two individuals in } \\
\text { the household }\end{array}$ & Binary variable: $1=$ if household has two family members; $0=$ otherwise & 333773 & 0.337 & 0.473 \\
\hline & $\begin{array}{l}\text { Three or more } \\
\text { individuals in the } \\
\text { household }\end{array}$ & Binary variable: $1=$ if household has three or more family members; $0=$ otherwise & 333773 & 0.522 & 0.500 \\
\hline $\begin{array}{l}\text { Living with } \\
\text { spouse }\end{array}$ & Living with spouse & Binary variable: $1=$ if individual is living with spouse; $0=$ otherwise & 333773 & 0.509 & 0.500 \\
\hline $\begin{array}{l}\text { Household } \\
\text { income }\end{array}$ & $\begin{array}{l}\text { Household income } \\
\text { (standardised } \\
\text { OECD equivalised) }\end{array}$ & $\begin{array}{l}\text { Household income variable is converted using OECD scale }{ }^{16} \text {. The new variable } \\
\text { is further rescaled (standardised) }\end{array}$ & 333343 & 1.330 & 1.000 \\
\hline \multirow{2}{*}{ 冚 } & Living comfortably & Binary variable: $1=$ if individual is living comfortably; $0=$ otherwise & 308982 & 0.290 & 0.454 \\
\hline & Doing alright & Binary variable: $1=$ if individual is doing alright; $0=$ otherwise & 308982 & 0.350 & 0.477 \\
\hline
\end{tabular}

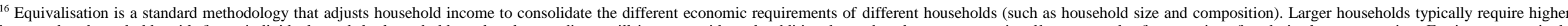

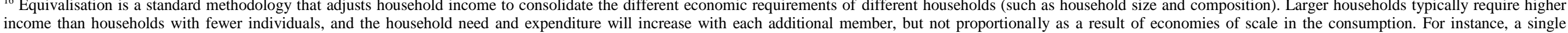

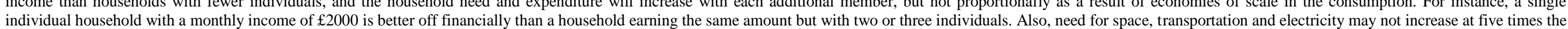

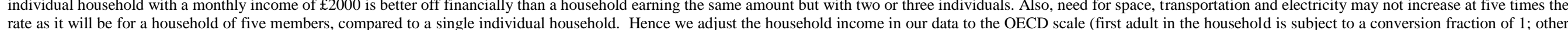

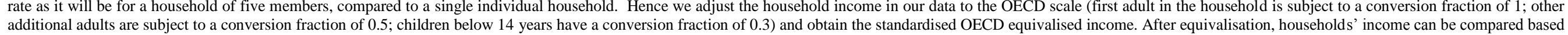
additional adults are subject to a conversion fraction of $0.5 ;$
} 


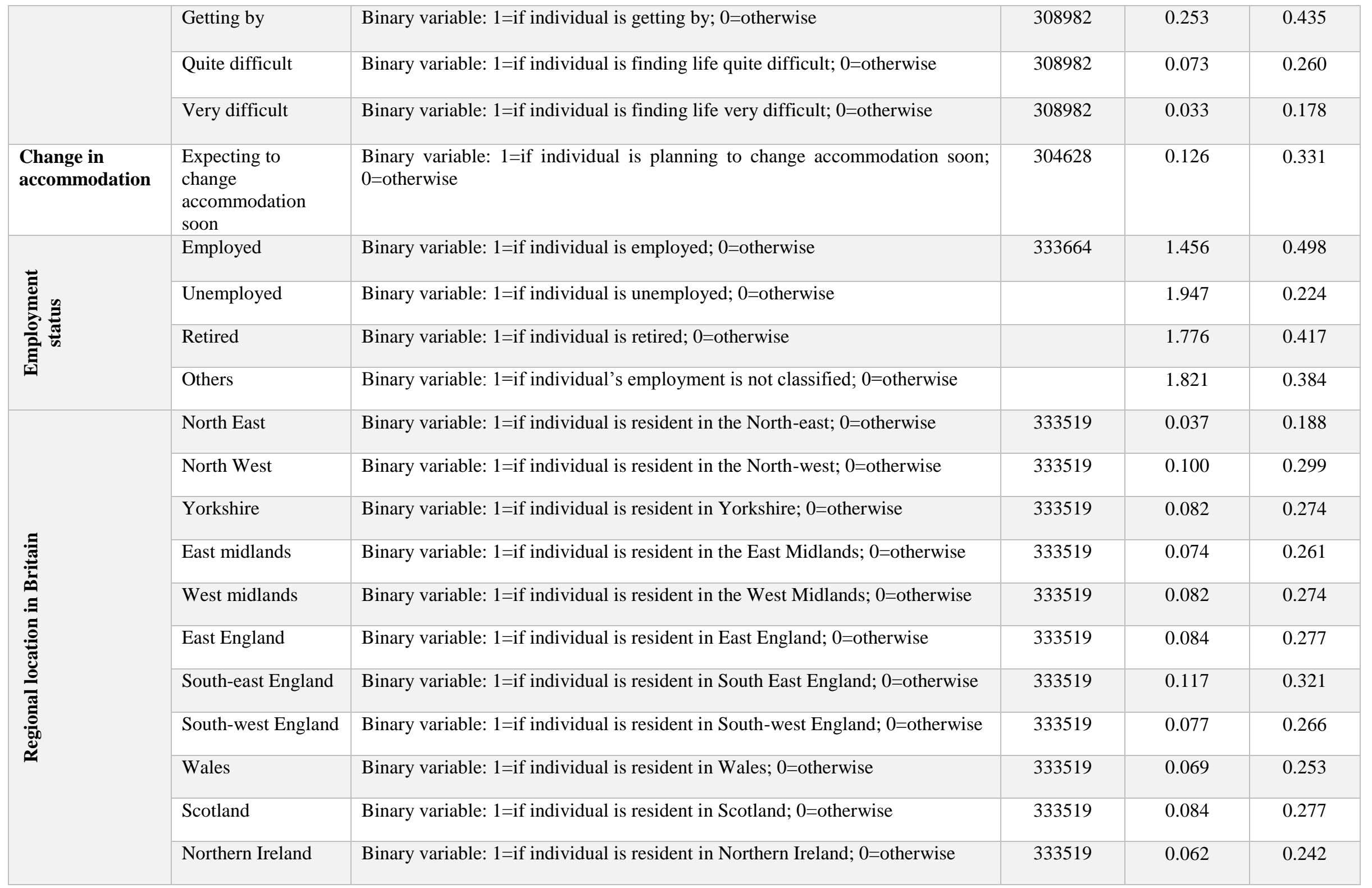


Table 2: Housing Tenure Outcomes: regional patterns

\begin{tabular}{|c|c|c|c|c|c|c|c|c|c|c|c|c|c|c|}
\hline & & (1) & (2) & (3) & (4) & (5) & (6) & (7) & $(8)$ & (9) & $(10)$ & (11) & (12) & (13) \\
\hline & VARIABLES & Baseline Model & London & Northeast & Northwest & Yorkshire & East midlands & West midlands & East England & South East & South West & Wales & Scotland & $\mathrm{N}$ Ireland \\
\hline \multirow{3}{*}{$\begin{array}{l}\text { Migration } \\
\text { generations }\end{array}$} & Natives & - & - & - & - & - & - & - & - & - & - & - & - & - \\
\hline & Second-generation & 0.006 & $0.047 * * *$ & -0.050 & 0.004 & -0.009 & 0.000 & -0.001 & 0.009 & 0.004 & -0.015 & -0.007 & 0.003 & 0.007 \\
\hline & First-generation & $-0.114 * * *$ & $-0.204 * * *$ & -0.048 & $-0.066 * * *$ & $-0.092 * * *$ & $-0.102 * * *$ & $-0.111 * * *$ & $-0.108 * * *$ & $-0.092 * * *$ & $-0.056^{* * * *}$ & $-0.039 *$ & $-0.081 * * *$ & $-0.090 * * *$ \\
\hline \multirow{6}{*}{ Age } & Age below 25 years & - & - & - & - & - & - & - & - & - & - & - & - & - \\
\hline & $25-34$ years & $-0.031 * * *$ & $-0.074 * * *$ & $-0.037^{*}$ & $-0.026 * *$ & 0.005 & $-0.027 * *$ & -0.015 & $-0.048 * * *$ & $-0.049 * * *$ & -0.014 & $-0.032 * *$ & -0.002 & $-0.037 * *$ \\
\hline & $35-44$ years & $0.044 * * *$ & $0.093 * * *$ & 0.004 & $0.032 * * *$ & $0.074 * * *$ & $0.061 * * *$ & $0.040 * * *$ & 0.015 & 0.015 & $0.087 * * *$ & $0.029^{*}$ & $0.036^{* * *}$ & 0.024 \\
\hline & $45-54$ years & $0.110^{* * *}$ & $0.221 * * *$ & $0.083^{* * *}$ & $0.101 * * *$ & $0.122 * * *$ & $0.121 * * *$ & $0.101 * * *$ & $0.085^{* * *}$ & $0.071 * * *$ & $0.149 * * *$ & $0.108 * * *$ & $0.064 * * *$ & $0.059 * * *$ \\
\hline & 55-64 years & $0.156^{* * * *}$ & $0.330 * * *$ & $0.122 * * *$ & $0.127 * * *$ & $0.179 * * *$ & $0.131 * * *$ & $0.158 * * *$ & $0.110 * * *$ & $0.122 * * *$ & $0.207 * * *$ & $0.134 * * *$ & $0.102^{* * * *}$ & $0.104 * * *$ \\
\hline & Over 65 years & $0.176^{* * * *}$ & $0.360^{* * * *}$ & $0.105 * * *$ & $0.158 * * *$ & $0.128 * * *$ & $0.156^{* * * *}$ & $0.208 * * *$ & $0.148 * * *$ & $0.155^{* * * *}$ & $0.213^{* * * *}$ & $0.151 * * *$ & $0.115^{* * *}$ & $0.148^{* * *}$ \\
\hline \multirow{6}{*}{$\begin{array}{l}\text { Educational } \\
\text { Qualification }\end{array}$} & Degree & - & - & - & - & - & - & - & - & - & - & - & - & - \\
\hline & No qualification & $-0.039 * * *$ & $-0.084 * * *$ & $-0.061 * *$ & $-0.061 * * *$ & $-0.033^{* *}$ & $-0.041 * *$ & -0.020 & $-0.035^{* *}$ & $-0.071 * * *$ & -0.001 & $-0.059 * * *$ & $-0.031 * *$ & $-0.037 * *$ \\
\hline & A-level & 0.001 & $0.026^{*}$ & -0.018 & -0.017 & 0.013 & $-0.036^{* * * *}$ & 0.016 & 0.012 & -0.009 & 0.015 & $-0.030 * *$ & -0.010 & -0.005 \\
\hline & GCSE & $-0.014 * * *$ & -0.012 & $-0.038^{*}$ & $-0.033^{* * *}$ & 0.003 & $-0.027^{*}$ & 0.001 & $-0.029 * *$ & -0.017 & -0.005 & $-0.036^{* *}$ & $-0.028 * *$ & 0.002 \\
\hline & Other higher degree & -0.004 & -0.028 & 0.027 & -0.021 & 0.005 & 0.005 & 0.001 & -0.016 & -0.003 & 0.006 & $-0.043 * *$ & -0.014 & 0.005 \\
\hline & Other qualification & $-0.031 * * *$ & $-0.054 * *$ & $-0.083 * * *$ & $-0.042 * * *$ & -0.002 & $-0.052^{* * * *}$ & -0.007 & $-0.032 *$ & $-0.027 *$ & -0.006 & $-0.045^{* *}$ & $-0.034 * *$ & $-0.036^{* *}$ \\
\hline Gender & Male & $-0.011 * * *$ & $-0.032 * * *$ & -0.004 & -0.004 & -0.008 & -0.002 & -0.009 & $-0.014 *$ & $-0.018 * *$ & $-0.017 *$ & -0.001 & -0.008 & 0.010 \\
\hline \multirow{6}{*}{ Race } & White & - & - & - & - & - & - & - & - & - & - & - & - & - \\
\hline & Black & -0.007 & $0.030 *$ & $-0.226 * * *$ & $-0.106 * * *$ & 0.007 & -0.000 & $0.044 * *$ & -0.025 & -0.033 & 0.038 & -0.072 & -0.018 & \\
\hline & Asian & $0.045^{* * *}$ & $0.069^{* * *}$ & -0.008 & $0.049 * * *$ & $0.123^{* * *}$ & $0.053^{* *}$ & $0.085^{* * *}$ & $0.042^{* *}$ & 0.023 & 0.031 & -0.008 & -0.010 & $-0.183^{* * *}$ \\
\hline & Arab/ Middle East & $-0.031 *$ & 0.029 & & -0.043 & -0.054 & 0.069 & -0.044 & -0.035 & 0.024 & -0.141 & & -0.088 & \\
\hline & Mixed Race & -0.014 & $0.058 * *$ & 0.074 & -0.040 & -0.048 & 0.019 & $-0.046^{*}$ & $-0.064 * *$ & -0.012 & -0.040 & 0.032 & -0.020 & 0.020 \\
\hline & Other race & -0.000 & 0.022 & 0.069 & 0.047 & $0.097 *$ & -0.028 & $-0.163 * *$ & -0.004 & $0.101 * *$ & & $-0.121 *$ & -0.020 & \\
\hline Urban dweller & Urban dweller & $0.012 * * *$ & -0.071 & 0.015 & 0.013 & 0.015 & $0.019 *$ & $0.050 * * *$ & 0.007 & 0.010 & $0.035^{* * *}$ & $0.023^{* *} *$ & $0.025 * * *$ & -0.014 \\
\hline Disabled & Disabled & $-0.010 * * *$ & 0.011 & -0.005 & -0.009 & 0.001 & -0.001 & $-0.019 * *$ & -0.007 & -0.007 & $-0.027 * * *$ & $-0.014 *$ & $-0.017 * * *$ & $-0.023 * * *$ \\
\hline \multirow{2}{*}{ Household size } & $\begin{array}{l}\text { Single individual } \\
\text { household }\end{array}$ & - & - & - & - & - & - & - & - & - & - & - & - & - \\
\hline & $\begin{array}{l}\text { Two individuals in } \\
\text { the household }\end{array}$ & $0.020 * * *$ & $0.041 * *$ & $-0.037 *$ & 0.014 & 0.014 & $0.041^{* * *}$ & 0.000 & 0.005 & 0.018 & $0.034 * *$ & -0.002 & $0.021 * *$ & $0.030 * *$ \\
\hline
\end{tabular}




\begin{tabular}{|c|c|c|c|c|c|c|c|c|c|c|c|c|c|c|}
\hline & $\begin{array}{l}\text { Three or more } \\
\text { individuals in the } \\
\text { household }\end{array}$ & $0.099 * * *$ & $0.169 * * *$ & $0.054 * *$ & $0.083 * * *$ & $0.075 * * *$ & $0.097 * * *$ & $0.080 * * *$ & $0.085 * * *$ & $0.094 * * *$ & $0.120 * * *$ & $0.058 * * *$ & $0.085 * * *$ & $0.101 * * *$ \\
\hline $\begin{array}{l}\text { Living with } \\
\text { spouse }\end{array}$ & Living with spouse & $0.053 * * *$ & $0.067 * * *$ & $0.086 * * *$ & $0.073 * * *$ & $0.053 * * *$ & $0.042 * * *$ & $0.039 * * *$ & $0.062 * * *$ & $0.051 * * *$ & $0.031 * * *$ & $0.060 * * *$ & $0.030 * * *$ & $0.038^{* * *}$ \\
\hline $\begin{array}{c}\text { Household } \\
\text { income }\end{array}$ & Household income & $0.024 * * *$ & $0.028 * * *$ & $0.045 * * *$ & $0.023 * * *$ & $0.047 * * *$ & $0.035 * * *$ & $0.029 * * *$ & $0.030 * * *$ & $0.021 * * *$ & $0.037 * * *$ & $0.015 * *$ & $0.026 * * *$ & $0.022 * * *$ \\
\hline \multirow{5}{*}{$\begin{array}{l}\text { Subjective } \\
\text { financial } \\
\text { wellbeing }\end{array}$} & Living comfortably & - & - & - & - & - & - & - & - & - & - & - & - & - \\
\hline & Doing alright & $-0.031 * * *$ & $-0.049 * * *$ & $-0.027 * *$ & $-0.034 * * *$ & $-0.033 * * *$ & $-0.029 * * *$ & $-0.026^{* * *}$ & $-0.023 * * *$ & $-0.031 * * *$ & $-0.045^{* * *}$ & $-0.026^{* * *}$ & $-0.013 * *$ & $-0.024 * * *$ \\
\hline & Getting by & $-0.068 * * *$ & $-0.089^{* * *}$ & $-0.069 * * *$ & $-0.062 * * *$ & $-0.079 * * *$ & $-0.050^{* * *}$ & $-0.057 * * *$ & $-0.062 * * *$ & $-0.074 * * *$ & $-0.097 * * *$ & $-0.051 * * *$ & $-0.038 * * *$ & $-0.041 * * *$ \\
\hline & Quite difficult & $-0.087 * * *$ & $-0.160 * * *$ & $-0.071 * * *$ & $-0.092 * * *$ & $-0.093 * * *$ & $-0.088 * * *$ & $-0.065^{* * *} *$ & $-0.079 * * *$ & $-0.081 * * *$ & $-0.100 * * *$ & $-0.049 * * *$ & $-0.040 * * *$ & $-0.063 * * *$ \\
\hline & Very difficult & $-0.108 * * *$ & $-0.194 * * *$ & $-0.050^{*}$ & $-0.111 * * *$ & $-0.098 * * *$ & $-0.067 * * *$ & $-0.099 * * *$ & $-0.097 * * *$ & $-0.124 * * *$ & $-0.137 * * *$ & $-0.101 * * *$ & $-0.076^{* * *}$ & $-0.047 * *$ \\
\hline $\begin{array}{c}\text { Expecting to } \\
\text { change } \\
\text { accommodation }\end{array}$ & $\begin{array}{l}\text { Expecting to change } \\
\text { accommodation }\end{array}$ & $-0.108 * * *$ & $-0.170 * * *$ & $-0.107 * * *$ & $-0.083 * * *$ & $-0.101 * * *$ & $-0.100 * * *$ & $-0.100 * * *$ & $-0.100 * * *$ & $-0.112 * * *$ & $-0.106 * * *$ & $-0.064 * * *$ & $-0.077 * * *$ & $-0.076 * * *$ \\
\hline \multirow{4}{*}{$\begin{array}{c}\text { Employment } \\
\text { status }\end{array}$} & Employed & - & - & - & - & - & - & - & - & - & - & - & - & - \\
\hline & Unemployed & $-0.031 * * *$ & -0.016 & $-0.103^{* * * *}$ & $-0.049 * * *$ & -0.021 & -0.001 & -0.020 & $-0.034^{*}$ & -0.015 & 0.009 & $-0.043 * *$ & $-0.065^{* * *}$ & $-0.075 * * *$ \\
\hline & Retired & $0.038^{* * *}$ & $0.076^{* * *}$ & $0.044^{* *}$ & $0.030^{* *}$ & $0.041 * *$ & $0.068^{* * *}$ & $0.031 *$ & $0.033^{* *}$ & $0.054^{* * *}$ & $0.041^{* * *}$ & 0.010 & $0.035^{* * *}$ & -0.004 \\
\hline & Others & $-0.049 * * *$ & $-0.033 * *$ & $-0.100 * * *$ & $-0.047 * * *$ & $-0.057 * * *$ & $-0.029 * *$ & $-0.046^{* * * *}$ & $-0.022 *$ & $-0.056^{* * *}$ & $-0.056^{* * * *}$ & $-0.055^{* * *}$ & $-0.076^{* * *}$ & $-0.054 * * *$ \\
\hline Pseudo $^{2}$ & & 0.221 & 0.277 & 0.226 & 0.214 & 0.212 & 0.216 & 0.216 & 0.222 & 0.240 & 0.233 & 0.178 & 0.241 & 0.205 \\
\hline Observations & & 220,906 & 24,640 & 7,984 & 22,716 & 18,168 & 16,940 & 18,633 & 19,488 & 27,727 & 18,227 & 14,555 & 17,912 & 13,823 \\
\hline
\end{tabular}

Robust standard errors in parentheses

$* * * \mathrm{p}<0.01, * * \mathrm{p}<0.05, * \mathrm{p}<0.1$ 
Table 3: Housing Tenure Outcomes: household income class






\begin{tabular}{|c|c|c|c|c|c|c|c|c|}
\hline & & $0.125 * * *$ & $0.169 * * *$ & $0.109 * * *$ & $0.085 * * *$ & $0.046 * * *$ & & $0.057 * * *$ \\
\hline \multirow{3}{*}{$\begin{array}{l}\text { Employment } \\
\text { status }\end{array}$} & Employed & - & - & - & - & & & \\
\hline & Unemployed & $\begin{array}{c}- \\
0.042 * * *\end{array}$ & $\begin{array}{c}- \\
0.050^{* * *}\end{array}$ & -0.016 & -0.006 & 0.006 & $0.022 * *$ & 0.003 \\
\hline & Others & $\begin{array}{c}- \\
0.057 * * *\end{array}$ & $\begin{array}{c}- \\
0.059 * * *\end{array}$ & $\begin{array}{c}- \\
0.034 * * *\end{array}$ & $\begin{array}{c}- \\
0.026 * * *\end{array}$ & $\begin{array}{c}- \\
0.023 * * *\end{array}$ & -0.011 & $0.021 * * *$ \\
\hline Pseudo r2 & & 0.217 & 0.261 & 0.205 & 0.185 & 0.153 & 0.152 & 0.189 \\
\hline Observations & & 221,120 & 50,591 & 55,770 & 42,097 & 25,479 & 13,364 & 15,143 \\
\hline
\end{tabular}

Robust standard errors in parentheses

$* * * \mathrm{p}<0.01, * * \mathrm{p}<0.05, * \mathrm{p}<0.1$

Table 4: Baseline Results (full sample) - marginal effects

\begin{tabular}{|c|c|c|c|c|c|}
\hline & & (1) & (2) & (3) & (4) \\
\hline & VARIABLES & $\begin{array}{c}\text { Baseline } \\
\text { Model }\end{array}$ & $\begin{array}{c}\text { With } \\
\text { Locational FE }\end{array}$ & $\begin{array}{c}\text { With Time } \\
\text { FE }\end{array}$ & $\begin{array}{c}\text { With Locational } \\
\text { and Time FE }\end{array}$ \\
\hline \multirow[t]{6}{*}{ Age } & $\begin{array}{l}\text { Age below } 25 \\
\text { years }\end{array}$ & - & - & - & - \\
\hline & $25-34$ years & $-0.054 * * *$ & $-0.053 * * *$ & $-0.054 * * *$ & $-0.053 * * *$ \\
\hline & $35-44$ years & $0.021 * * *$ & $0.021 * * *$ & $0.021 * * *$ & $0.021 * * *$ \\
\hline & $45-54$ years & $0.089 * * *$ & $0.089 * * *$ & $0.089 * * *$ & $0.089 * * *$ \\
\hline & 55-64 years & $0.134 * * *$ & $0.135 * * *$ & $0.134 * * *$ & $0.135 * * *$ \\
\hline & Over 65 years & $0.154 * * *$ & $0.157 * * *$ & $0.155 * * *$ & $0.158 * * *$ \\
\hline \multirow{6}{*}{$\begin{array}{c}\text { Educational } \\
\text { Qualification }\end{array}$} & Degree & - & - & - & - \\
\hline & $\begin{array}{l}\text { No } \\
\text { qualification }\end{array}$ & $-0.036 * * *$ & $-0.043^{* * *}$ & $-0.037 * * *$ & $-0.044 * * *$ \\
\hline & A-level & $0.009 * * *$ & 0.005 & $0.009 * *$ & 0.005 \\
\hline & GCSE & 0.000 & -0.004 & 0.000 & -0.004 \\
\hline & $\begin{array}{l}\text { Other higher } \\
\text { degree }\end{array}$ & 0.000 & -0.004 & 0.000 & -0.004 \\
\hline & $\begin{array}{l}\text { Other } \\
\text { qualification }\end{array}$ & $-0.029 * * *$ & $-0.033 * * *$ & $-0.030 * * *$ & $-0.033 * * *$ \\
\hline Gender & Male & $-0.008 * * *$ & $-0.008 * * *$ & $-0.008 * * *$ & $-0.008 * * *$ \\
\hline \multirow[t]{6}{*}{ Race } & White & - & - & - & - \\
\hline & Black & $-0.073 * * *$ & $-0.045 * * *$ & $-0.072 * * *$ & $-0.044 * * *$ \\
\hline & Asian & $-0.021 * * *$ & -0.005 & $-0.020 * * *$ & -0.004 \\
\hline & $\begin{array}{l}\text { Arab/ Middle } \\
\text { East }\end{array}$ & $-0.112 * * *$ & $-0.091 * * *$ & $-0.111 * * *$ & $-0.090 * * *$ \\
\hline & Mixed Race & $-0.042 * * *$ & $-0.025 * * *$ & $-0.042 * * *$ & $-0.024 * * *$ \\
\hline & Other race & $-0.070 * * *$ & $-0.049 * * *$ & $-0.070 * * *$ & $-0.049 * * *$ \\
\hline Urban dweller & Urban dweller & $0.007 * *$ & $0.014 * * *$ & $0.007 * *$ & $0.015 * * *$ \\
\hline Disabled & Disabled & $-0.009 * * *$ & $-0.010^{* * *}$ & $-0.009 * * *$ & $-0.010 * * *$ \\
\hline \multirow[t]{2}{*}{ Household size } & $\begin{array}{l}\text { Single } \\
\text { individual } \\
\text { household }\end{array}$ & - & - & - & - \\
\hline & $\begin{array}{l}\text { Two } \\
\text { individuals in } \\
\text { the household }\end{array}$ & $0.023 * * *$ & $0.023 * * *$ & $0.023 * * *$ & $0.023 * * *$ \\
\hline
\end{tabular}




\begin{tabular}{|c|c|c|c|c|c|}
\hline & $\begin{array}{l}\text { Three or more } \\
\text { individuals in } \\
\text { the household }\end{array}$ & $0.106 * * *$ & $0.105^{* * *}$ & $0.106 * * *$ & $0.106 * * *$ \\
\hline $\begin{array}{l}\text { Living with } \\
\text { spouse }\end{array}$ & $\begin{array}{l}\text { Living with } \\
\text { spouse }\end{array}$ & $0.046 * * *$ & $0.045^{* * *}$ & $0.046 * * *$ & $0.045 * * *$ \\
\hline $\begin{array}{l}\text { Household } \\
\text { income }\end{array}$ & $\begin{array}{l}\text { Household } \\
\text { income }\end{array}$ & $0.026 * * *$ & $0.029 * * *$ & $0.027 * * *$ & $0.030 * * *$ \\
\hline \multirow{5}{*}{$\begin{array}{l}\text { Subjective } \\
\text { financial } \\
\text { wellbeing }\end{array}$} & $\begin{array}{l}\text { Living } \\
\text { comfortably }\end{array}$ & - & - & - & - \\
\hline & Doing alright & $-0.034 * * *$ & $-0.034 * * *$ & $-0.035 * * *$ & $-0.034 * * *$ \\
\hline & Getting by & $-0.072 * * *$ & $-0.070 * * *$ & $-0.073 * * *$ & $-0.071 * * *$ \\
\hline & Quite difficult & $-0.095 * * *$ & $-0.093 * * *$ & $-0.096 * * *$ & $-0.094 * * *$ \\
\hline & Very difficult & $-0.118 * * *$ & $-0.114 * * *$ & $-0.119 * * *$ & $-0.116 * * *$ \\
\hline $\begin{array}{c}\text { Expecting to } \\
\text { change } \\
\text { accommodation }\end{array}$ & $\begin{array}{l}\text { Expecting to } \\
\text { change } \\
\text { accommodatio } \\
\mathrm{n}\end{array}$ & $-0.112 * * *$ & $-0.110 * * *$ & $-0.113 * * *$ & $-0.110 * * *$ \\
\hline \multirow{4}{*}{$\begin{array}{c}\text { Employment } \\
\text { status }\end{array}$} & Employed & - & - & - & - \\
\hline & Unemployed & $-0.033 * * *$ & $-0.032 * * *$ & $-0.033 * * *$ & $-0.032 * * *$ \\
\hline & Retired & $0.043 * * *$ & $0.042 * * *$ & $0.043 * * *$ & $0.042 * * *$ \\
\hline & Others & $-0.044 * * *$ & $-0.043 * * *$ & $-0.043 * * *$ & $-0.043 * * *$ \\
\hline \multirow{12}{*}{$\begin{array}{c}\text { Regional } \\
\text { locations in } \\
\text { Britain/Regional } \\
\text { Fixed Effects }\end{array}$} & London & - & - & - & - \\
\hline & North East & $\mathrm{NO}$ & $0.043 * * *$ & NO & $0.044 * * *$ \\
\hline & North West & NO & $0.061 * * *$ & NO & $0.061 * * *$ \\
\hline & Yorkshire & $\mathrm{NO}$ & $0.061 * * *$ & NO & $0.061 * * *$ \\
\hline & East midlands & NO & $0.056^{* * *}$ & NO & $0.057 * * *$ \\
\hline & West midlands & NO & $0.064 * * *$ & NO & $0.064 * * *$ \\
\hline & East England & $\mathrm{NO}$ & $0.049 * * *$ & NO & $0.049 * * *$ \\
\hline & $\begin{array}{l}\text { South-east } \\
\text { England }\end{array}$ & NO & $0.039 * * *$ & NO & $0.039 * * *$ \\
\hline & $\begin{array}{l}\text { South-west } \\
\text { England }\end{array}$ & NO & $0.036 * * *$ & NO & $0.036 * * *$ \\
\hline & Wales & NO & $0.066^{* * *}$ & NO & $0.066^{* * *}$ \\
\hline & Scotland & $\mathrm{NO}$ & $0.082 * * *$ & $\mathrm{NO}$ & $0.082 * * *$ \\
\hline & $\begin{array}{l}\text { Northern } \\
\text { Ireland }\end{array}$ & NO & $0.075^{* * *}$ & NO & $0.075^{* * *}$ \\
\hline \multirow{6}{*}{$\begin{array}{c}\text { Waves/time fixed } \\
\text { effects }\end{array}$} & 2.wave & $\mathrm{NO}$ & $\mathrm{NO}$ & $0.011 * * *$ & $0.009 * * *$ \\
\hline & 3.wave & NO & NO & $0.010 * * *$ & $0.007 * * *$ \\
\hline & 4.wave & NO & NO & $0.007 * * *$ & $0.004 * *$ \\
\hline & 5.wave & $\mathrm{NO}$ & NO & 0.003 & 0.000 \\
\hline & 6.wave & NO & NO & $-0.006^{* * *}$ & $-0.009 * * *$ \\
\hline & 7.wave & NO & NO & $-0.008 * * *$ & $-0.011 * * *$ \\
\hline Constant & & $0.703 * * *$ & $0.385^{* * *}$ & $0.688 * * *$ & $0.381 * * *$ \\
\hline Observations & & 243,774 & 243,774 & 243,774 & 243,774 \\
\hline Pseudo r2 & & 0.198 & 0.204 & 0.199 & 0.204 \\
\hline
\end{tabular}

Robust standard errors in parentheses $* * * \mathrm{p}<0.01, * * \mathrm{p}<0.05,{ }^{*} \mathrm{p}<0.1$ 
Table 5: Baseline Models with Locational and Time-Fixed Effects for Natives, Secondgeneration and First-generation Migrants

\begin{tabular}{|c|c|c|c|c|c|}
\hline & & (1) & (2) & (3) & (4) \\
\hline & VARIABLES & All observations & Natives & $\begin{array}{c}\text { Second- } \\
\text { generation }\end{array}$ & $\begin{array}{c}\text { First- } \\
\text { generation }\end{array}$ \\
\hline \multirow[t]{6}{*}{ Age } & Age below 25 years & - & - & - & - \\
\hline & 25-34 years & $-0.053 * * *$ & $-0.019 * * *$ & $-0.045 * * *$ & $-0.051 * * *$ \\
\hline & $35-44$ years & $0.021 * * *$ & $0.045 * * *$ & $0.033 * *$ & $0.085 * * *$ \\
\hline & 45-54 years & $0.089 * * *$ & $0.094 * * *$ & $0.105 * * *$ & $0.251 * * *$ \\
\hline & $55-64$ years & $0.135^{* * * *}$ & $0.132 * * *$ & $0.149 * * *$ & $0.353 * * *$ \\
\hline & Over 65 years & $0.158 * * *$ & $0.150 * * *$ & $0.204 * * *$ & $0.385 * * *$ \\
\hline \multirow{6}{*}{$\begin{array}{l}\text { Educational } \\
\text { Qualification }\end{array}$} & Degree & - & - & - & - \\
\hline & No qualification & $-0.044 * * *$ & $-0.056 * * *$ & $-0.043 * *$ & 0.005 \\
\hline & A-level & 0.005 & $-0.011 * * *$ & -0.009 & $0.041 * * *$ \\
\hline & GCSE & -0.004 & $-0.024 * * *$ & $-0.022 *$ & 0.027 \\
\hline & Other higher degree & -0.004 & $-0.009 *$ & $-0.051 * * *$ & 0.027 \\
\hline & Other qualification & $-0.033 * * *$ & $-0.027 * * *$ & $-0.052 * * *$ & $-0.070 * * *$ \\
\hline Gender & Male & $-0.008 * * *$ & -0.003 & -0.009 & $-0.061 * * *$ \\
\hline \multirow[t]{6}{*}{ Race } & White & - & - & - & - \\
\hline & Black & $-0.044 * * *$ & 0.019 & 0.010 & 0.006 \\
\hline & Asian & -0.004 & $0.053 * *$ & $0.074 * * *$ & $0.082 * * *$ \\
\hline & Arab/ Middle East & $-0.090 * * *$ & & $0.113 * *$ & -0.055 \\
\hline & Mixed Race & $-0.024 * * *$ & $-0.031 * *$ & -0.010 & 0.036 \\
\hline & Other race & $-0.049 * * *$ & $-0.072 *$ & 0.023 & 0.031 \\
\hline Urban dweller & Urban dweller & $0.015 * * *$ & $0.021 * * *$ & -0.006 & $-0.047 * *$ \\
\hline Disabled & Disabled & $-0.010 * * *$ & $-0.016 * * *$ & 0.000 & $0.034 * * *$ \\
\hline \multirow[t]{3}{*}{ Household size } & $\begin{array}{l}\text { Single individual } \\
\text { household }\end{array}$ & - & - & - & - \\
\hline & $\begin{array}{l}\text { Two individuals in the } \\
\text { household }\end{array}$ & $0.023 * * *$ & $0.016 * * *$ & $0.024 *$ & 0.019 \\
\hline & $\begin{array}{l}\text { Three or more } \\
\text { individuals in the } \\
\text { household }\end{array}$ & $0.106^{* * *}$ & $0.089 * * *$ & $0.125 * * *$ & $0.093 * * *$ \\
\hline $\begin{array}{l}\text { Living with } \\
\text { spouse }\end{array}$ & Living with spouse & $0.045 * * *$ & $0.046 * * *$ & $0.030 * * *$ & $0.125 * * *$ \\
\hline $\begin{array}{c}\text { Household } \\
\text { income }\end{array}$ & Household income & $0.030 * * *$ & $0.022 * * *$ & $0.017 * * *$ & 0.063 *** \\
\hline \multirow{5}{*}{$\begin{array}{l}\text { Subjective } \\
\text { financial } \\
\text { wellbeing }\end{array}$} & Living comfortably & - & - & - & - \\
\hline & Doing alright & $-0.034 * * *$ & $-0.029 * * *$ & $-0.020 * * *$ & $-0.048 * * *$ \\
\hline & Getting by & $-0.071 * * *$ & $-0.063 * * *$ & $-0.067 * * *$ & $-0.082 * * *$ \\
\hline & Quite difficult & $-0.094 * * *$ & $-0.078 * * *$ & $-0.102 * * *$ & $-0.131 * * *$ \\
\hline & Very difficult & $-0.116 * * *$ & $-0.107 * * *$ & $-0.103 * * *$ & $-0.143 * * *$ \\
\hline $\begin{array}{c}\text { Expecting to } \\
\text { change } \\
\text { accommodation }\end{array}$ & $\begin{array}{l}\text { Expecting to change } \\
\text { accommodation }\end{array}$ & $-0.110 * * *$ & $-0.080 * * *$ & $-0.111 * * *$ & $-0.241 * * *$ \\
\hline \multirow{4}{*}{$\begin{array}{l}\text { Employment } \\
\text { status }\end{array}$} & Employed & & & & \\
\hline & Unemployed & $-0.032 * * *$ & $-0.037 * * *$ & -0.005 & $-0.039 * *$ \\
\hline & Retired & $0.042 * * *$ & $0.038 * * *$ & 0.016 & $0.049 *$ \\
\hline & Others & $-0.043 * * *$ & $-0.052 * * *$ & $-0.058 * * *$ & $-0.041 * * *$ \\
\hline Regional & London & - & - & - & - \\
\hline
\end{tabular}




\begin{tabular}{cl|cccc}
\hline locations in & North East & $0.044^{* * *}$ & $0.021^{* *}$ & $-0.074^{* *}$ & $0.129^{* * *}$ \\
Britain/Regional & North West & $0.061^{* * *}$ & $0.031^{* * *}$ & 0.002 & $0.146^{* * *}$ \\
& Fixed Effects & $0.061^{* * *}$ & $0.031^{* * *}$ & 0.013 & $0.161^{* * *}$ \\
& Yorkshire & $0.057^{* * *}$ & $0.034^{* * *}$ & 0.008 & $0.096^{* * *}$ \\
& East midlands & $0.064^{* * *}$ & $0.034^{* * *}$ & 0.019 & $0.119^{* * *}$ \\
& West midlands & $0.049^{* * *}$ & $0.034^{* * *}$ & 0.009 & $0.062^{* * *}$ \\
& East England & $0.039^{* * *}$ & $0.022^{* * *}$ & -0.005 & $0.057^{* * *}$ \\
& South-east England & $0.036^{* * *}$ & $0.015^{* *}$ & -0.025 & $0.113^{* * *}$ \\
& South-west England & $0.066^{* * *}$ & $0.039^{* * *}$ & -0.001 & $0.125^{* * *}$ \\
& Wales & $0.082^{* * *}$ & $0.056^{* * *}$ & $0.039^{*}$ & $0.083^{* * *}$ \\
& Scotland & $0.075^{* * *}$ & $0.057^{* * *}$ & 0.032 & 0.012 \\
\hline Waves/Time & Northern Ireland & - & - & - & - \\
Fixed Effects & Wave 1 & $0.009^{* * *}$ & -0.001 & 0.001 & $0.030^{* * *}$ \\
& Wave 2 & $0.007 * * *$ & $-0.008^{* * *}$ & 0.000 & $0.041^{* * *}$ \\
& Wave 3 & $0.004^{* * *}$ & $-0.014^{* * *}$ & -0.001 & $0.046^{* * *}$ \\
& Wave 4 & 0.000 & $-0.019^{* * *}$ & $-0.011^{*}$ & $0.051^{* * *}$ \\
& Wave 5 & $-0.009^{* * *}$ & $-0.029^{* * *}$ & $-0.020^{* * *}$ & $0.040^{* * *}$ \\
& Wave 6 & $-0.011^{* * *}$ & $-0.032^{* * *}$ & $-0.026^{* * *}$ & $0.028^{* * *}$ \\
\hline Observations & Wave 7 & 243,774 & 165,788 & 22,715 & 32,402 \\
Pseudo r2 & & $\mathbf{0 . 2 0 4}$ & $\mathbf{0 . 2 0 5}$ & $\mathbf{0 . 1 8 9}$ & $\mathbf{0 . 2 6 3}$ \\
\hline
\end{tabular}


Table 6: Lifecycle Effects across Models (First-generation only)

\begin{tabular}{l|cc}
\hline & $(1)$ & $(2)$ \\
\hline VARIABLES & Lifecycle Effects only & Migration Lifecycle \\
\hline Lifecycle (Age) & $0.113^{* * *}$ & $0.030^{* * *}$ \\
Migration Lifecycle & NO & $0.124^{* * *}$ \\
\hline Educational Qualification & YES & YES \\
Gender & YES & YES \\
Race & YES & YES \\
Urban dweller & YES & YES \\
Disabled & YES & YES \\
Household size & YES & YES \\
Living with spouse & YES & YES \\
Household income & YES & YES \\
Subjective financial & & \\
wellbeing & YES & YES \\
Expecting to change & YES & YES \\
accommodation & YES & YES \\
Employment status & & \\
Regional locations in & YES & YES \\
Britain/Regional Fixed & 32,402 & 32,402 \\
Effects & $\mathbf{0 . 2 5 5 3}$ & $\mathbf{0 . 3 2 8}$ \\
Waves/Time Fixed Effects & Observations & Pseudo r2
\end{tabular}

Robust standard errors in parentheses $* * * \mathrm{p}<0.01, * * \mathrm{p}<0.05,{ }^{*} \mathrm{p}<0.1$ 
Table 7: Migration Lifecycle Effects across Models (Calibrated variables)

\begin{tabular}{|c|c|c|c|}
\hline & & (1) & (2) \\
\hline & VARIABLES & $\begin{array}{c}\text { Lifecycle } \\
\text { effects only }\end{array}$ & $\begin{array}{l}\text { Migration } \\
\text { Lifecycle }\end{array}$ \\
\hline \multirow[t]{6}{*}{ Lifecycle (Age) } & Below 25 years & - & - \\
\hline & 25-34 years & $-0.084 * * *$ & $-0.019 * * *$ \\
\hline & $35-44$ years & $-0.041 * *$ & $0.045 * * *$ \\
\hline & 45-54 years & 0.030 & $0.094 * * *$ \\
\hline & 55-64 years & $0.053 * *$ & $0.132 * * *$ \\
\hline & Over 65 years & 0.051 & $0.150 * * *$ \\
\hline \multirow[t]{7}{*}{ Migration Lifecycle } & Less than 10 years & $\mathrm{NO}$ & - \\
\hline & 10-19 years & NO & $0.223 * * *$ \\
\hline & 20-29 years & NO & $0.368 * * *$ \\
\hline & $30-39$ years & $\mathrm{NO}$ & $0.453 * * *$ \\
\hline & 40-49 years & $\mathrm{NO}$ & $0.494 * * *$ \\
\hline & $50-59$ years & NO & $0.512 * * *$ \\
\hline & Over 60 years & NO & $0.519 * * *$ \\
\hline \multicolumn{2}{|l|}{ Educational Qualification } & YES & YES \\
\hline \multicolumn{2}{|l|}{ Gender } & YES & YES \\
\hline \multicolumn{4}{|l|}{ Race } \\
\hline \multicolumn{2}{|l|}{ Urban dweller } & YES & YES \\
\hline \multicolumn{2}{|l|}{ Disabled } & YES & YES \\
\hline \multicolumn{2}{|l|}{ Household size } & YES & YES \\
\hline \multicolumn{2}{|l|}{ Living with spouse } & YES & YES \\
\hline \multicolumn{2}{|l|}{ Household income } & YES & YES \\
\hline \multicolumn{2}{|l|}{$\begin{array}{l}\text { Subjective financial } \\
\text { wellbeing }\end{array}$} & YES & YES \\
\hline \multicolumn{2}{|l|}{$\begin{array}{l}\text { Expecting to change } \\
\text { accommodation }\end{array}$} & YES & YES \\
\hline \multicolumn{2}{|l|}{ Employment status } & YES & YES \\
\hline \multirow{4}{*}{\multicolumn{2}{|c|}{$\begin{array}{l}\text { Regional locations in } \\
\text { Britain/Regional Fixed } \\
\text { Effects } \\
\text { Waves/Time Fixed Effects }\end{array}$}} & YES & YES \\
\hline & & & \\
\hline & & & \\
\hline & & YES & YES \\
\hline \multicolumn{2}{|l|}{ Observations } & 32,402 & 32,402 \\
\hline \multicolumn{2}{|l|}{ Pseudo r2 } & 0.263 & 0.341 \\
\hline
\end{tabular}

Robust standard errors in parentheses $* * * p<0.01, * * p<0.05, * p<0.1$ 